\title{
Responsabilidad de los establecimientos bancarios por el pago de cheques falsos o alterados en Colombia*
}

\section{Jorge Alberto Padilla Sánchez ${ }^{* *}$ \\ I Málory Zafra Sierra}

Resumen: En la actualidad nos encontramos ante la presencia de una tendencia de la actividad jurisdiccional colombiana encaminada a acudir a criterios objetivos de responsabilidad de los establecimientos bancarios por el incumplimiento de sus obligaciones contractuales, con el fin de proteger al consumidor financiero, como sujeto de especial protección por parte del ordenamiento jurídico. Tal vez uno de los casos más emblemáticos de los que se enmarcan en dicha tendencia es el de la responsabilidad de los establecimientos bancarios por el pago de cheques falsos o alterados, que cuenta con un régimen legal que permite distinguirlo del régimen general de responsabilidad de dichas entidades, razón por la cual se hace necesario su estudio y análisis.

Este artículo es producto de las labores de investigación desarrolladas dentro de la Línea de Investigación en Responsabilidad Civil del Grupo de Derecho Privado de la Universidad Externado de Colombia. Fecha de recepción: 2 de septiembre de 20I6. Fecha de aceptación: 8 de mayo de 2017 . Para citar el artículo: Padilla Sánchez, J. A. y Zafra Sierra, M., "Responsabilidad de los establecimientos bancarios por el pago de cheques falsos o alterados en Colombia", Revista de Derecho Privado, Universidad Externado de Colombia, n. ${ }^{\circ} 32$, enero-junio de 2017 , 383-420. DOI: https://doi.org/ro.186or/or 234366.n32.13

** Especialización en Derecho Comercial de la Universidad Externado de Colombia. Candidato a LL.M. in Securitires and Financial Regulation (maestría en Regulación Financiera y Bursátil) de Georgetown University y a miembro del New York State Bar Examination. Docente investigador del Departamento de Derecho Civil de la Universidad Externado de Colombia, Bogotá, Colombia. Contacto: jorge.padilla@uexternado.edu.co

*** Abogada de la Universidad Externado de Colombia. Candidata a especialista en Seguros de la misma universidad. Docente investigadora del Departamento de Derecho Civil de la Universidad Externado de Colombia, Bogotá, Colombia. Contacto: malory.zafra@uexternado.edu.co. Los autores agradecen la colaboración de Miguel Ángel Moreno Bocarejo para la elaboración de este artículo. 
Palabras clave: Pago de cheque falso, consumidor financiero, responsabilidad del establecimiento bancario, responsabilidad profesional.

\section{Liability of Banking Institutions for the Payment of Forged or Altered Checks in Colombia}

Aвstract: We face a trend to turn liability of financial institutions to strict liability for breach of their contractual obligations, trend that has been extended by the Colombian judicial activity to situations that do not have legal grounds, under the pretext of protecting the financial consumer as a subject of special protection by the law. Perhaps one of the most emblematic cases of this trend is the responsibility of banking institutions for payment of counterfeit or adulterated checks, which does have a legal mandate that allows distinguish it from the general system of responsibility of such entities.

KEYwords: Forged-check payment, financial consumer, banking institutions' liability, professional liability.

Sumario: Introducción. I. Responsabilidad contractual de los establecimientos bancarios. A. Relaciones entre los establecimientos bancarios y el consumidor. B. El daño proviene de la inejecución de obligaciones nacidas del contrato. C. La culpa como fundamento de la responsabilidad contractual. II. Fundamento teórico de un régimen objetivo de responsabilidad por el pago de cheques falsos o alterados. A. El concepto de riesgo. B. El riesgo en la actividad financiera. C. Desarrollo legislativo de la responsabilidad de los establecimientos bancarios por el pago de cheques falsos o alterados en Colombia. D. Desarrollo jurisprudencial de la responsabilidad de los establecimientos bancarios por el pago de cheques falsos o alterados en Colombia. Conclusiones. Bibliografía.

\section{Introducción}

De antaño se ha puesto de presente la importancia de la intervención estatal en el sector financiero, debido a que se trata de una actividad de interés público ${ }^{\mathrm{I}}$ que conlleva la necesidad de preservar la estabilidad de la economía y de la moneda, garantizar la democratización del crédito, regular el adecuado financiamiento de

I Art. 335 C.N.: "Las actividades financiera, bursátil, aseguradora y cualquier otra relacionada con el manejo, aprovechamiento e inversión de los recursos de captación a las que se refiere el literal d) del numeral ig del artículo i 50 son de interés público y sólo pueden ser ejercidas previa autorización del Estado, conforme a la ley, la cual regulará la forma de intervención del Gobierno en estas materias y promoverá la democratización del crédito”. 
los consumidores, entre otros ${ }^{2}$. En este contexto, el Estado colombiano ha realizado una labor de regulación y supervisión de las distintas entidades financieras, la cual se ha traducido, entre otros aspectos, en la elaboración e introducción en el ordenamiento jurídico de regímenes particulares de responsabilidad de las entidades financieras. En este texto nos ocuparemos del régimen de responsabilidad de los establecimientos bancarios por el pago de cheques falsos o alterados.

Así las cosas, el legislador se ha encargado de establecer un marco regulatorio especial con respecto a la responsabilidad de los establecimientos bancarios por el pago de cheques falsos o alterados, distinguiéndolo del régimen general de responsabilidad de dichas entidades por el incumplimiento de sus obligaciones en el seno de sus relaciones contractuales. En efecto, el legislador ha pretendido alejar dicho régimen de responsabilidad del concepto de culpa y establecer, de este modo, un sistema de responsabilidad objetiva en beneficio del consumidor financiero. Así mismo, dicho marco regulatorio ha sido complementado y dotado de contenido por parte de la jurisprudencia nacional, la cual no ha manejado una línea constante o estable, sino que ha variado y presentado distintas posturas sobre el particular, circunstancia que justifica el análisis de la responsabilidad de dichas entidades, en particular por el pago de cheques falsos o alterados.

Cabe resaltar en este punto que el planteamiento de un régimen particular de responsabilidad para el caso de cheques falsos goza de un fundamento normativo que lo dota de legitimidad. En este sentido, se justifica su estudio de manera particular, a fin de determinar las razones por las cuales el legislador tomó la decisión de separarlo del régimen general de responsabilidad, máxime cuando en la actualidad el aparato jurisdiccional ha pretendido extender dicho régimen a situaciones que no tienen un soporte normativo que lo permita, con el pretexto de proteger al consumidor financiero como sujeto de especial protección por parte del ordenamiento jurídico. En primer lugar, se realizará una descripción del régimen normativo de la responsabilidad de las entidades financieras, que por regla general responde a un régimen subjetivo. Para tal efecto será necesario determinar qué tipo de relación existe entre tales entidades financieras y el consumidor, pues su especial naturaleza da lugar a la existencia de un conjunto

"Ahora, bajo ese contexto, la intervención del Estado en el sistema financiero se dirige fundamentalmente a otorgar la seguridad y confianza que las entidades vigiladas por la Superintendencia Bancaria deben proporcionarle al público en general. Ello por cuanto no se está frente a una actividad exclusivamente privada, carente de interés social y ajena a la intervención del Estado. Por el contrario en dicha actividad está involucrado el ahorro de la comunidad y las personas jurídicas que la desarrollan actúan en ejercicio de una autorización que les da el Estado para cumplir con sus fines, entre los que se destaca la prestación de un servicio público, por lo cual la función bancaria no puede asimilarse a la que desarrolla cualquier particular en ejercicio de la autonomía privada, pues tal y como lo señala el citado artículo 335 la actividad financiera es de interés público y en esa medida debe buscar siempre el bienestar general": Superintendencia Bancaria (hoy Superintendencia Financiera de Colombia). Concepto n. ${ }^{\circ} 200105477$ I-3 del I4 de octubre de 2004 . 
de deberes especiales que dan alcance a la responsabilidad que aquellas asumen frente a estos. De este modo, se presentará un marco general que permita abordar el punto central de la investigación, esto es, el análisis de la responsabilidad de los establecimientos bancarios por el pago de cheques falsos o alterados en Colombia. En la segunda parte se analizarán las razones por las cuales la aplicación de dicho régimen se justifica en el caso que nos ocupa, es decir, se estudiarán las razones que dan lugar a la separación de un régimen subjetivo en el caso de pago de cheques falsos o alterados. En este contexto se presentará el desarrollo legislativo que ha tenido la materia, para luego abordar su desarrollo jurisprudencial y concluir con la explicación del estado del arte. En este último punto se ilustrarán de manera crítica las distintas posturas que ha tenido la jurisprudencia colombiana sobre el particular.

\section{Responsabilidad contractual de los establecimientos bancarios}

En esta primera parte del texto realizaremos una aproximación al régimen de responsabilidad contractual de los establecimientos bancarios 3 , lo cual permitirá plantear el marco general, del cual se distingue la responsabilidad de dichas entidades financieras por el pago de cheques falsos y alterados. En este sentido, es menester, en un primer momento, plantear las particulares características y naturaleza de la relación existente entre las entidades y los consumidores financieros, pues de su alcance se desprende un conjunto de deberes y obligaciones a su cargo, ante cuyo incumplimiento deben responder por los perjuicios que se lleguen a causar. En particular, y como se profundizará con posterioridad, la especial naturaleza de la relación impone a las entidades financieras el cumplimiento de estándares más estrictos de diligencia. Así las cosas, se realizará un estudio a propósito del daño como fruto del incumplimiento o inejecución de las obligaciones contractuales, para luego poder analizar la culpa como fundamento de la responsabilidad contractual de dichas entidades.

Comoquiera que el presente texto se limita al estudio del incumplimiento de las obligaciones de los intervinientes en la operación que nacen de las relaciones negociales que los gobiernan, nos circunscribiremos al estudio de su

3 Desde ya debe precisarse que el concepto de institución financiera comprende el conjunto de entidades que componen el sistema financiero (art. I EOSF), dentro de las cuales se encuentran los establecimientos de crédito, cuya función consiste en "captar en moneda legal recursos del público en depósitos, a la vista o a término, para colocarlos nuevamente a través de préstamos, descuentos, anticipos u otras operaciones activas de crédito" (art. 2 núm. I EosF). En el mismo sentido, dentro de estos se encuentran los establecimientos bancarios, que tienen como objeto social "la captación de recursos en cuenta corriente bancaria, así como también la captación de otros depósitos a la vista o a término, con el objeto primordial de realizar operaciones activas de crédito" (art. 2 núm. 2 ESOF). Así las cosas, son los establecimientos bancarios quienes se encargan de celebrar contratos de cuenta corriente, de los cuales se desprende el uso de chequeras, razón por la cual nos referiremos siempre a dichas entidades financieras a lo largo del presente texto. 
responsabilidad contractual, la cual opera en un campo limitado, esto es, frente al incumplimiento de obligaciones que nacen de un contrato que genera perjuicios, y únicamente frente a las partes contractuales.

En este orden de ideas, la doctrina ha sentado cuáles son los presupuestos necesarios para que opere la responsabilidad contractual:

... la aplicación de la responsabilidad contractual supone no solamente que un contrato existe entre la víctima y el autor del daño en el momento en que este se produce (i), sino, además, que ese daño resulta de la inejecución de una obligación nacida de ese contrato o vinculada a él (ii), y que la responsabilidad sea puesta en juego en las relaciones entre contratantes o personas asimiladas a contratantes (iii) 4 .

A continuación abordaremos cada uno de estos elementos, así como ciertas vicisitudes que pueden presentarse en torno a la responsabilidad civil contractual de las entidades financieras, y con posterioridad en particular por el pago de cheques falsos o alterados.

\section{A. Relaciones entre los establecimientos bancarios y el consumidor}

Es preciso recordar que entre las entidades financieras y los consumidores financieros existe una relación de naturaleza y características particulares que lleva consigo la aplicación de estándares o parámetros más exigentes con respecto al nivel de diligencia que aquellas deben observar normalmente en la prestación de sus productos y servicios, circunstancia que responde al deber a cargo del Estado de abogar por la protección del consumidor (art. 79 C.N.).

En ese sentido, al momento de determinar la debida diligencia de las entidades financieras en sus relaciones con los consumidores financieros, es preciso señalar que aquellas son profesionales y que se encuentran frente a estos en una posición de asimetría contractual 5 , lo cual implica que la diligencia que debe exigírseles a dichas entidades en el cumplimiento de sus obligaciones frente al ordenante o beneficiario ha de ser más estricta. El parámetro de conducta debe

4 G. Viney, Tratado de derecho civil. Introducción a la responsabilidad, trad. Fernando Montoya, Bogotá, Universidad Externado de Colombia, 2007, 380.

5 "Ésta es la primera característica que surge de la ley y que suele destacarse doctrinalmente acerca del consumidor o usuario (términos equivalentes), y se da un paso más al fondo en torno a su ya referida debilidad contractual, que, al profundizársela, pasa a ser una verdadera vulnerabilidad. "Es que el derecho de los consumidores tiene una bandera que es ésta, con la verdadera contrapartida de la superioridad de las contrapartes proveedoras. Y tiene a la vez, por así decir, dos escoltas, que son clásicos en su literatura: la contratación en masa o serie, por adhesión y predispuesta, que comúnmente suele exteriorizarse por su abusividad en distintos aspectos que la caracterizan y a la que me referiré ulteriormente": C. G. Gerscovich, Consumidores bancarios. Derechos económicos de los bancos y sus clientes, Buenos Aires, Abeledo-Perrot, 201 I, IO2. 
ser el comportamiento que llevaría a cabo una entidad financiera como profesional en el cumplimiento de sus obligaciones.

En este punto ha de mencionarse que el numeral 3 del artículo $5 .^{\circ}$ de la Ley I 480 de 20 I I, por la cual se expide el Estatuto del Consumidor, brinda una definición del concepto de "consumidor" en el siguiente sentido:

Toda persona natural o jurídica que, como destinatario final, adquiera, disfrute o utilice un determinado producto, cualquiera que sea su naturaleza para la satisfacción de una necesidad propia, privada, familiar o doméstica y empresarial cuando no esté ligada intrínsecamente a su actividad económica. Se entenderá incluido en el concepto de consumidor el de usuario.

Así, para el régimen general, es consumidor toda persona que adquiera un producto como destinatario final para la satisfacción de una necesidad.

Adicionalmente, la Ley I 328 de 2009 define al consumidor financiero como "todo cliente, usuario o cliente potencial de las entidades vigiladas" (art. 2 lit. d). Así mismo, define el concepto de cliente como "la persona natural o jurídica con quien las entidades vigiladas establecen relaciones de origen legal o contractual, para el suministro de productos o servicios, en desarrollo de su objeto social" (art. 2 lit. a); y el concepto de cliente potencial como "la persona natural o jurídica que se encuentra en la fase previa de tratativas preliminares con la entidad vigilada, respecto de los productos o servicios ofrecidos por esta" (art. 2 lit c). De esta forma, no cabe duda que, al no hacer distinción alguna sobre la calidad de la persona como cliente o cliente potencial, cualquier persona, natural o jurídica, que establezca relaciones contractuales para el suministro de productos o servicios o se encuentre en fase previa de tratativas preliminares es un consumidor financiero ${ }^{6}$.

En este contexto, nos encontramos ante dos regímenes de protección al consumidor, respecto de lo cual es oportuno resaltar que la Ley I 328 de 2009, encargada de la protección al consumidor financiero, contiene las normas que han de ser de aplicación preferente, toda vez que se trata de una norma especial de cara al régimen general7. Ahora bien, no se trata de dos complejos normativos

6 "Las situaciones descritas en torno a 'consumidor financiero' abarcan a toda persona natural o jurídica, sin que concierna sobre esa calidad la existencia o no de desigualdades y asimetrías, o de circunstancias de necesidad o conveniencia, dado que las profundas desigualdades 'inmanentes' al mercado y al consumo, explicadas por esta corporación a partir de los postulados del artículo 78 superior, son suficientes y superan cualquier incertidumbre, duda o especulación, una vez elevada a categoría constitucional el amparo de los derechos del consumidor": Corte Constitucional, Sentencia C-909 de 20 г 2, M.P.: Nilson Pinilla Pinilla.

7 "En ese orden de ideas, para determinar si los artículos de la Ley I480 de 20 I I se aplican o no a las relaciones de los consumidores financieros con las entidades vigiladas, será necesario revisar en cada caso si el régimen de la Ley I 328 de 2009 regula de manera integral la situación, evento en el cual se aplicará de preferencia dicha normativa antes de acudir a las generales contenidas en el Estatuto del Consumidor": Superintendencia Financiera de Colombia. Concepto $2013008465-008$ del 8 de julio de 2013 . 
excluyentes o que se encuentren dirigidos en opuestos sentidos sino que, por el contrario, deben ser complementados en el marco de la búsqueda de un equilibrio contractual en aquellas relaciones que por su naturaleza resultan ser asimétricas. Así las cosas, el régimen general de protección al consumidor únicamente resulta aplicable de cara al consumidor financiero ante la ausencia de regulación por parte del Estatuto de Protección al Consumidor Financiero.

Por otro lado, debe recordarse que la jurisprudencia constitucional ha reconocido que las entidades financieras son sujetos calificados encargados de realizar una actividad de interés público ${ }^{8}$, lo cual implica la exigencia de un deber de diligencia más demandante 9 . En efecto, las entidades financieras, de manera profesional, ponen a disposición de sus clientes productos y servicios financieros por los cuales reciben un beneficio económico, razón por la cual su diligencia debe observarse dentro del marco de la naturaleza de las actividades que desarrollan.

Así las cosas, entre ambas partes existe una situación de asimetría negocial que determina el contenido y alcance de las obligaciones que integran sus relaciones contractuales, ante cuyo incumplimiento han de ser encontradas responsables por los perjuicios que puedan causarse. En este sentido, toda institución financiera realiza una actividad especializada que requiere de una mayor prudencia, de acuerdo con el conocimiento de su actividad, razón por la cual su conducta debe medirse con base en parámetros más severos que aquellos de los particulares.

\section{B. El daño proviene de la inejecución de obligaciones nacidas del contrato}

El daño generado al acreedor por el incumplimiento de las obligaciones propias del contrato ${ }^{\mathrm{IO}}$ debe ser reparado. El deudor debe responder por todos los daños

8 “... la actividad financiera, bursátil y aseguradora es, pues, una actividad esencial para el desarrollo económico; constituye principal mecanismo de administración del ahorro del público y de financiación de la inversión pública y privada y está fundada en un pacto intangible de confianza. Se trata de la confianza por parte de los usuarios en que las obligaciones derivadas de la respectiva obligación serán rutinariamente satisfechas. Y esa confianza está a su vez cimentada en una regulación adecuada y en la convicción pública de que las entidades que hacen parte del sistema están vigiladas técnica y profesionalmente": Corte Constitucional. Sentencia C-640 del I 8 de agosto de 20 Iо, M.P.: Mauricio González Cuervo.

9 "Esta especial protección a la actividad bursátil, fundada en la confianza pública inmersa en su gestión, exige de las sociedades que la ejercen, mayor diligencia y profesionalismo, toda vez que, como prestadora del servicio, posee un amplio margen de control de las operaciones, servicios por los cuales recibe una retribución por parte de los clientes, generando un régimen especial en sus relaciones contractuales, lo que conlleva que la entidad cumpla con las obligaciones que le son exigibles y asuma los riesgos inherentes del ejercicio masivo y profesional de su actividad, atendiendo los deberes implícitos de la misma": Superintendencia Financiera de Colombia. Sentencia del 27 de mayo de 2015 , rad. $2013-0808$.

Io "Daño no significa más que nocimiento o perjuicio, es decir, aminoración o alteración de una situación favorable": A. DE CupIs, El daño. Teoría general de la responsabilidad civil, trad. Á. Martínez Sarrión, Barcelona, Bosch, I970, 8 I. 
y perjuicios culposos que sean previsibles o previstos al tiempo del contrato (art. I6 I6 c. c.) ${ }^{\text {II }}$. Sobre el particular se ha pronunciado Hinestrosa al indicar que "el resarcimiento proviene del daño causado al transgredir la fórmula concreta que vinculaba exclusivamente a demandante y demandado, que no podía ser conculcada sino por éste, que beneficiaba solo al primero, y que constituía aplicación precisa del deber universal de respeto a los derechos ajenos y corrección en la conducta, procedente e inderogable" ${ }^{\prime 2}$.

En este sentido, en el ordenamiento jurídico la tasación de los daños y perjuicios responde a un principio de reparación integral, según el cual el perjuicio es el límite de la reparación; esto es, se debe indemnizar el perjuicio en su integridad, sin poder ir más allá de este (art. I6 Ley 446 de I998) ${ }^{13}$. Lo que pretende este principio es colocar a la víctima del daño en la situación en la que se encontraría de no haberse concretado el hecho dañino. En todo caso, es preciso señalar que en materia contractual la reparación puede ser limitada. En efecto, el artículo r6 I6 c. c. ${ }^{14}$ permite a los particulares incluir en sus relaciones contractuales pactos o negocios jurídicos dirigidos a exonerar o limitar las consecuencias derivadas de su incumplimiento. Estas medidas legislativas permiten modificar los regímenes de responsabilidad con base en el ejercicio de la autonomía privada y la libertad contractual, afectando el principio de reparación integral ${ }^{15}$. Así pues, el carácter relativo obtiene su sustento en el principio de autonomía privada.

I I Art. i6r6 c. c.: "Si no se puede imputar dolo al deudor, solo es responsable de los perjuicios que se previeron o pudieron preverse al tiempo del contrato; pero si hay dolo, es responsable de todos los perjuicios que fueron consecuencia inmediata o directa de no haberse cumplido la obligación o de haberse demorado su cumplimiento.

"La mora producida por fuerza mayor o caso fortuito, no da lugar a indemnización de perjuicios.

"Las estipulaciones de los contratantes podrán modificar estas reglas".

i 2 Hinestrosa, F. Derecho civil. Obligaciones, Bogotá, Universidad Externado de Colombia, ig69, 587 .

I3 Art. I6 Ley 446 de I998: "Dentro de cualquier proceso que se surta ante la Administración de Justicia, la valoración de daños irrogados a las personas y a las cosas, atenderá los principios de reparación integral y equidad y observará los criterios técnicos actuariales”.

I4 Art. r6r6 c. c.: "Si no se puede imputar dolo al deudor, solo es responsable de los perjuicios que se previeron o pudieron preverse al tiempo del contrato; pero si hay dolo, es responsable de todos los perjuicios que fueron consecuencia inmediata o directa de no haberse cumplido la obligación o de haberse demorado su cumplimiento.

"La mora producida por fuerza mayor o caso fortuito, no da lugar a indemnización de perjuicios.

"Las estipulaciones de los contratantes podrán modificar estas reglas".

I 5 "Cabe resaltar que en materia contractual, la reparación del daño debe estar orientada también por el principio general según el cual la víctima tiene derecho a la reparación total de los daños que sean ciertos, directos, personales y que hayan causado la supresión de un beneficio obtenido lícitamente por el afectado. Esta reparación debe comprender tanto los perjuicios patrimoniales como extrapatrimoniales. Sin embargo, en materia convencional, este principio general puede estar limitado ya sea por cláusulas legislativas razonables, o por estipulaciones de los contratantes, quienes autónomamente pueden decidir que el responsable se libere total o parcialmente de su obligación frente a la víctima, habida cuenta del interés privado que está inmerso en los 
Cabe recordar en este punto que todo deudor debe cumplir con sus obligaciones de acuerdo con la manera como hayan sido pactadas en el contrato (art. I62 7 c. c.) ${ }^{\mathrm{I} 6}$. De ahí que deba responder frente a su acreedor por su inejecución o por el retardo en su cumplimiento ${ }^{17}$. Ahora bien, el contenido obligacional del contrato no se limita a aquello que haya sido estipulado de manera expresa, sino que sobrepasa las disposiciones de las partes para ser integrado por un conjunto de obligaciones adicionales provenientes del principio de buena $\mathrm{fe}^{\mathrm{I} 8}$. Así lo indica el artículo I603 c. c.: "Los contratos deben ejecutarse de buena fe, y por consiguiente obligan no sólo a lo que en ellos se expresa, sino a todas las cosas que emanan precisamente de la naturaleza de la obligación o que por la ley pertenecen a ella".

En este orden de ideas, el incumplimiento de los mandatos de la buena fe, como lo son los deberes de lealtad, honestidad, información o transparencia que deben regir las relaciones comerciales, da lugar también a la responsabilidad contractual por los perjuicios que dicha actuación pueda causar a la contraparte contractual. Ahora bien, en el campo contractual nos referimos únicamente a la buena fe objetiva como fuente de obligaciones, la cual ha sido entendida como el principio jurídico y la regla de conducta que integra el contenido del negocio jurídico, imponiendo deberes y obligaciones a las partes contractuales de conformidad con postulados de honestidad, rectitud y lealtad ${ }^{19}$.

derechos de crédito asociados a un contrato. En este sentido, el inciso final del artículo I6I6 parcialmente acusado establece que 'Las estipulaciones de los contratos podrán modificar estas reglas": Corte Constitucional. Sentencia C-roo8 de 20ro, M.P.: Luis Ernesto Vargas Silva.

i6 Art. I627 c. c.: "El pago se hará bajo todos respectos en conformidad al tenor de la obligación; sin perjuicio de lo que en los casos especiales dispongan las leyes.

"El acreedor no podrá ser obligado a recibir otra cosa que lo que se le deba, ni aún a pretexto de ser de igual o mayor valor la ofrecida".

I 7 "La obligación se considera transgredida a partir del momento en que el deudor se coloca en mora si la prestación es positiva, y cuando se ejecuta el hecho prohibido si es negativa, fechas desde las cuales son demandables los perjuicios ( $\mathrm{I}_{6} \mathrm{I}_{5}$ ), y para saber oportunidad y demás aspectos del pago necesario es necesario acudir al título que muestra época, contenido y alcances del deber": Hinestrosa. Derecho civil, cit., 590.

I8 "De aquello que se determina convencionalmente, es decir, las disposiciones que se pueden referir al acuerdo de las partes y que constituyen el contenido es necesario diferenciar lo que es la integración, es decir, las determinaciones que hacen parte de la relación y que tienen su título en la ley o en otras fuentes externas al contrato (fuentes heterónomas).

"La regla de fondo de la integración prevé que el contrato obliga a las partes no sólo a aquello que en él se expresó, sino también a todas las consecuencias que se derivan según la ley o, a falta de ella, según los usos y la equidad (art. 1374 C.C.). Otra fuente de derecho objetivo de la relación contractual a la que es necesario reconocer una preminencia particular es la buena fe (art. I 375 C.C.)": M. Bianca, Derecho civil. El contrato, trads. F. Hinestrosa y É. Cortés, Bogotá, Universidad Externado de Colombia, 2007, $52 \mathrm{I}$.

I9 "De manera que este tipo de buena fe se erige en regla de conducta fundada en la honestidad, en la rectitud, en la lealtad y principalmente en la consideración del interés del otro visto como un miembro del conjunto social que es jurídicamente tutelado": M. L. Neme Villarreal, "Buena fe subjetiva y buena fe objetiva", Revista de Derecho Privado, Universidad Externado de Colombia, n. ${ }^{\circ}$ I $7,2009,49$. 
En este sentido, las entidades financieras cuentan con una serie de obligaciones de seguridad respecto de los productos financieros que ofrecen a los consumidores financieros. Dentro de estas obligaciones se encuentra la necesidad de elaborar perfiles de acuerdo con la costumbre transaccional de cada cliente y poder, de este modo, establecer los procedimientos necesarios para la confirmación de operaciones que se encuentren por fuera de su perfil o costumbre transaccional ${ }^{20}$.

En el mismo sentido, el ordenamiento jurídico se ha encargado de imponer un conjunto de deberes y obligaciones a las entidades financieras en el ejercicio de sus relaciones contractuales. La omisión de cualquiera de estos podrá hacer que dichas entidades incurran en responsabilidad contractual. Así, por ejemplo, el literal a) del artículo 5 de la Ley I $_{3} 28$ de 2009 dispone que es un derecho de los consumidores, y un deber correlativo para las entidades financieras, recibir productos y servicios que cumplan con estándares de seguridad y calidad ${ }^{2}{ }^{1}$. Se trata de los parámetros mínimos en los que se debe enmarcar el cumplimiento de las obligaciones de las entidades financieras ${ }^{22}$. Sobre el particular se ha pronunciado la Superintendencia Financiera de Colombia en el siguiente sentido:

... de conformidad con lo señalado en el literal a) del artículo 5 de la Ley I 328 de 2009 , los Consumidores financieros tienen "durante todos los momentos de

20 Superintendencia Financiera de Colombia, Delegatura para Funciones Jurisdiccionales. Sentencia del 20 de marzo de 2013 .

2 I Art. 5 Ley I 328 de 2009: "Sin perjuicio de los derechos consagrados en otras disposiciones legales vigentes, los consumidores financieros tendrán, durante todos los momentos de su relación con la entidad vigilada, los siguientes derechos:

“a) En desarrollo del principio de debida diligencia, los consumidores financieros tienen el derecho de recibir de parte de las entidades vigiladas productos y servicios con estándares de seguridad y calidad, de acuerdo con las condiciones ofrecidas y las obligaciones asumidas por las entidades vigiladas".

22 “... dentro de los estándares generales mínimos establecidos para la seguridad de los dineros depositados por el consumidor financiero, resultan relevantes para el presente análisis los establecidos en el Capítulo Décimo Segundo del Título Primero de la Circular Básica Jurídica n. ${ }^{\circ}$ o07 de 1996 sobre obligaciones generales respecto de la seguridad y calidad del servicio que prestan y específicamente sobre el canal de internet: (i) Establecer procedimientos para el bloqueo de canales o instrumentos para la realización de operaciones cuando existan situaciones o hechos que lo ameriten o después de un número de accesos fallidos por parte de un cliente, así como las medidas operativas y de seguridad para la reactivación de los mismos (num. 3.I.I2); (ii) Elaborar el perfil de las costumbres transaccionales de cada uno de sus clientes y definir procedimientos para la confirmación oportuna de las operaciones monetarias que no correspondan a sus hábitos (num. 3.I.I3); (iii) Informar adecuadamente a los clientes respecto de las medidas de seguridad que deberán tener en cuenta para la realización de operaciones por cada canal, así como los procedimientos para el bloqueo, inactivación, reactivación y cancelación de los productos y servicios ofrecidos (num. 3.4.4); (iv) Implementar los algoritmos y protocolos necesarios para brindar una comunicación segura (núm. 4.9.I); y, (v) Promover y poner a disposición de sus clientes mecanismos que reduzcan la posibilidad de que la información de sus operaciones monetarias pueda ser capturada por terceros no autorizados durante cada sesión": Superintendencia Financiera de Colombia. Sentencia del 20 de marzo de 2013, rad. 20 I 2 -OI 2 I. 
su relación con la entidad vigilada”, el derecho de recibir de parte de las entidades "productos y servicios con estándares de seguridad y calidad, de acuerdo con las condiciones ofrecidas y las obligaciones asumidas por las entidades vigiladas" ([resaltado] fuera del texto), entendiendo que tal derecho y su obligación correlativa, se encuentran incorporados al contrato celebrado entre ellos de conformidad con lo establecido en ese mismo canon normativo. En igual sentido, el literal f) del artículo 5 ibídem, indica que aquellos derechos que se encuentren inmersos en la Ley o en las instrucciones impartidas por esta Superintendencia, cobijarán las relaciones existentes entre los consumidores financieros y las entidades vigiladas, por lo que, ante la existencia de un contrato entre estos, en el mismo se entienden incorporados los derechos consagrados en tales disposiciones normativas ${ }^{23}$.

Así las cosas, la elaboración de un perfil transaccional del cliente tiene fundamento en el deber de las entidades financieras de prestar servicios y ofrecer productos con estándares de seguridad y calidad, ante cuyo incumplimiento han de responder por los perjuicios causados. Es así como deberán definir procedimientos para la confirmación de las operaciones monetarias que no correspondan a sus hábitos. Se trata de un criterio de seguridad que tiene una gran incidencia sobre la responsabilidad de los establecimientos bancarios por el pago de cheques falsos en Colombia, toda vez que (i) la omisión de elaborar dicho perfil y procedimientos de confirmación, así como (ii) las actuaciones del banco sin tener en cuenta dicho perfil, pueden hacer responsable al establecimiento.

\section{La culpa como fundamento de la responsabilidad contractual}

Una de las normas que resultan fundamentales y que sienta los parámetros en el análisis de la responsabilidad contractual es el artículo i604 c. c., en virtud del cual el deudor incumplido deberá responder de conformidad con la graduación de culpa consagrada en el artículo $6_{3}$ ibídem, que brinda mayores luces en cuanto al concepto y contenido de la culpa contractual.

Teniendo en cuenta que, como regla general, en los contratos donde participan entidades financieras ambas partes contractuales reportan un beneficio, sus intervinientes han de responder hasta por culpa leve, entendida esta como la falta de diligencia y de cuidado que debe emplearse ordinariamente en los propios negocios. Se trata de un parámetro de referencia objetivo que corresponde a la actuación que en dicha situación se hubiera desplegado en el cuidado que debe emplearse ordinariamente en los propios negocios, y no aquella que en particular hubiera desplegado el deudor ${ }^{24}$.

23 Superintendencia Financiera de Colombia. Sentencia del 24 de enero de 20I3, rad. 20 I 2-o69.

24 "En tratándose del cumplimiento de las obligaciones, esa regla de diligencia encuentra un 'punto culminante' de actuación, toda vez que del deudor se exige, generalmente, el cumplimiento 
Probada por su parte la diligencia, el deudor deberá ser exonerado de responsabilidad. Sin embargo, no en todos los casos ocurre de esta manera, pues el tipo de obligación asumida determinará la conducta exigible al deudor, según que se trate de obligaciones de medios o de resultado. En el caso de las obligaciones de medios, el deudor responde por la ausencia del resultado de conformidad con un criterio subjetivo, y se libera con la prueba de haber desplegado una actividad diligente ${ }^{25}$. En estos casos, los obligados adquieren el deber de actuar con la diligencia propia que debe emplearse ordinariamente en los propios para cumplir con las prestaciones. Deberán responder en caso de que el incumplimiento se derive de su actuación culposa o negligente ${ }^{26}$.

Sobre el particular es necesario indicar que la Ley I 328 de 2009 incorporó como principio del régimen de protección al consumidor financiero la debida diligencia de las entidades financieras en el ofrecimiento de productos o prestación de servicios a los consumidores financieros. Se trata de una precisión puntual del parámetro de diligencia del buen hombre de negocios que fue plasmada de la siguiente manera:

Las entidades vigiladas por la Superintendencia Financiera de Colombia deben emplear la debida diligencia en el ofrecimiento de sus productos o en la prestación de sus servicios a los consumidores, a fin de que estos reciban la información y/o la atención debida y respetuosa en desarrollo de las relaciones que establezcan con aquellas, y en general, en el desenvolvimiento normal de sus operaciones (art. 3 Ley I 328 de 2009).

En este sentido, el análisis de la conducta de dichas entidades debe necesariamente partir de la noción de culpa, que se traduce en el incumplimiento del deber de debida diligencia arriba descrito.

de su prestación desplegando el comportamiento propio de un buen padre de familia; pero si se trata del cumplimiento de obligaciones inherentes al ejercicio profesional, su diligencia debe aquilatarse, entonces, teniendo como referencia la naturaleza de la actividad desarrollada": Corte Suprema de Justicia, Sala de Casación Civil. Sentencia del I4 de junio de 2000, exp. 5025.

25 "Se considera que bien lejos de comprometerse a procurar al acreedor un resultado, el deudor contractual se compromete solamente a hacer lo necesario para que ese resultado pueda ser obtenido. Por tanto, su responsabilidad no puede ser deducida sino en cuanto no puso por obra los medios necesarios para alcanzar el resultado previsto por las partes. En otros términos, la culpa del deudor es una condición de la responsabilidad contractual, culpa que consiste en no haber hecho lo que era posible para satisfacer al acreedor": C. Larroumet, Droit civil. Les obligations, t. 3, Paris, Economica, 1986, 49.

26 "En los países de derecho civil, para que exista responsabilidad civil, debe existir un incumplimiento culposo de la prestación prometida, imputable al deudor de la prestación y del cual se haya derivado un daño al acreedor de la misma. Estos elementos (culpa, imputabilidad, daño, y relación causa-efecto entre culpa y el daño), se aplican a la responsabilidad documentaria como a cualquier otro tipo de responsabilidad contractual o extracontractual": J-O. RoDNER. El crédito documentario, Caracas, I989, 4 I 7 . 
Ahora bien, en el caso de las obligaciones de resultado, el parámetro de la responsabilidad por la ausencia del resultado es más estricto, por cuanto no basta probar la debida diligencia para que el deudor se exonere de $\operatorname{responsabilidad}^{27}$. Así lo expone Larroumet:

Hay situaciones en las cuales el deudor está obligado a la reparación del daño sufrido por el acreedor en cuanto este no haya obtenido satisfacción. Más precisamente, cuando el acreedor no haya obtenido lo debido por el deudor, ha de admitirse el principio de la responsabilidad, sin que sea necesario que el acreedor pruebe que el deudor no puso en ejecución los medios necesarios para satisfacerlo. En otros términos, la prueba de una culpa del deudor no es condición necesaria de la responsabilidad. En cuanto no se obtiene el resultado prometido, el deudor debe ser condenado a reparar el daño sufrido por el acreedor ${ }^{28}$.

En estos casos, la responsabilidad del deudor nace por el solo incumplimiento de sus obligaciones, sin que sea necesario analizar su conducta diligente o culpo$\mathrm{sa}^{29}$. Sin embargo, debe precisarse que como regla general las obligaciones que adquieren las entidades financieras son de medios y no de resultado.

Ahora bien, sin importar si nos encontramos frente a obligaciones de medios o de resultado, lo que realmente resulta trascendente para el deudor es que para exonerarse de responsabilidad deba probar cuál fue el evento que le impidió cumplir, carga que se justifica en el hecho de que él es la única persona que tiene los medios necesarios para poder explicar lo sucedido; de ahí que el artículo r604 c. c. disponga que la prueba de la diligencia le corresponde al deudor, y la prueba del caso fortuito a quien lo alega (art. I 733 c. c.), que en últimas siempre será el deudor, por cuanto con el elemento extraño se exonerará.

\section{Fundamento teórico de un régimen objetivo de responsabilidad por el pago de cheques falsos o alterados}

Luego de haber planteado el marco general del régimen de responsabilidad de las entidades financieras, nos corresponde en este punto estudiar su ámbito de responsabilidad por el pago de cheques falsos o alterados. De entrada cabe seña-

27 V. Roppo, Instituzioni di diritto privato, Bologna, Monduzzi, I 994, 309.

28 Larroumet, ob. cit., 48.

29 "Ahora bien, el predicado pierde fuerza en las hipótesis de responsabilidad contractual que nos ocupan porque en la medida que no se produzca el resultado esperado por el cliente, que debería fluir del cumplimiento de la obligación asumida por el banco, se tiene por incumplido el contrato y se genera una responsabilidad para el banco de la que sólo puede relevarse si prueba que lo ocurrido obedece a una causa externa e insoportable [...] o se origina en hecho de tercero, de las mismas características o en la culpa de la propia víctima, vale decir, del cliente": S. Rodríguez Azuero, Contratos bancarios. Su significación en América Latina, Legis, 2009, I 74. 
lar que en Colombia dicho régimen se ha balanceado entre sistemas subjetivos y sistemas objetivos de responsabilidad, lo cual hace necesario realizar unos breves comentarios sobre el concepto de riesgo y en particular su desenvolvimiento y papel en el sistema financiero colombiano.

\section{A. El concepto de riesgo}

En este punto, y con el fin de generar claridad conceptual para poder abordar el tema, resulta necesario delimitar el concepto de riesgo, elemento que imprime un carácter objetivo al análisis de la responsabilidad. El riesgo ha sido entendido como la contingencia de un daño ${ }^{30}$; como la posibilidad o potencialidad de concreción de un daño.

La idea de riesgo, con su introducción en la órbita del análisis de la responsabilidad, pretendió reemplazar la culpa como su elemento estructural principal. Esta subrogación implicaba un enfrentamiento con el principio según el cual no hay responsabilidad sin culpa probada, lo cual tenía como consecuencia que se le otorgara una gran importancia al elemento del daño y no ya al de la culpa. $\mathrm{Al}$ reemplazar la categoría de culpa por la de riesgo, como base estructural de la responsabilidad, se introduce un régimen de responsabilidad objetiva, en tanto se dejan de lado las consideraciones volitivas o internas de quien ha causado el daño.

Cabe mencionar en este punto que la noción de riesgo ha presentado un conjunto de variantes y matices que es menester explicar ${ }^{3}$. En primer lugar, se ha hecho referencia al riesgo provecho, según el cual si una persona obtiene beneficios de una actividad, tiene a su cargo la obligación de indemnizar perjuicios que se ocasionen como consecuencia de esta. En este sentido, quien obtenía un provecho por la introducción en la sociedad de una actividad riesgosa, debía asumir los daños que ella causara a terceros.

"El riesgo, entendido como la contingencia de un daño, delimita la estructura de la responsabilidad a un factor meramente objetivo: el perjuicio; por lo tanto, quien cause un daño a otro está en la obligación de indemnizarlo, es éste el principio básico de la responsabilidad para la teoría objetiva, y que sin buscar apoyos distintos de los estrictamente legislativos, se encuentra contenido en el artículo I 494 del Código Civil, que al contemplar las fuentes de las obligaciones establece como una de éstas, "el hecho que ha inferido injuria o daño a otra persona": M. G. Sarmiento García, La responsabilidad en el transporte aéreo de personas, tesis de grado, Universidad Externado de Colombia, I978, i 28.

3 I "A fines del Siglo Xix, surgen las doctrinas del 'riesgo profesional' (risque professionnel, Raymond Saleilles [i 855-I9I 2]), 'riesgo creado' (risque crée, Louis Josserand [I868-I94I]), 'riesgo beneficio', 'riesgo de empresa' y postulan la responsabilidad, no por culpa, sino por la asunción de una empresa o una actividad riesgosa en contraprestación al beneficio que de ella se recibe $(u b i$ emolumentum ibi onus o ubi commoda ibi et incommoda o cuius commoda eius incommoda esse debet), bien por equidad, en tanto, el deber surgiría ex lege para quien genera el riesgo, dispone de una cosa, ejerce su gobierno o tiene su control": Corte Suprema de Justicia, Sala de Casación Civil. Sentencia del 24 de agosto de 2009, exp. I IOOI3 I03038200I-OIO54-OI. 
En segundo lugar, se encuentra la teoría del riesgo creado, según la cual "la responsabilidad es consecuencia inevitable de ejercer una actividad que crea riesgos para las demás personas" $3^{2}$; es decir, "toda actividad que crea para otro un riesgo hace a su autor responsable del daño que pueda causar sin que haya lugar a investigar si hubo culpa o no de su parte"33. Así las cosas, quien ha creado una actividad riesgosa debe responder por los posibles o eventuales daños que esta ocasione, sin importar si con ella obtuvo o no un provecho o enriquecimiento.

Finalmente, la teoría del riesgo profesional consiste en una modalidad del riesgo en la que no solo se exige la obtención de un beneficio económico, sino además la existencia de una actividad calificada como especializada o técnica, es decir, se tiene en cuenta el concepto de profesionalismo ${ }^{34}$. En este contexto, el riesgo profesional tiene su fundamento en las conductas realizadas de manera profesional que implican riesgos para terceros ${ }^{35}$.

\section{B. El riesgo en la actividad financiera}

Dicho lo anterior, es oportuno señalar que el riesgo tiene un rol fundamental dentro de la actividad financiera. Como se ha indicado en el derecho comparado, "toda inversión involucra un riesgo" 36 , lo cual lleva a considerar que toda actividad financiera, y en general toda actividad empresarial, lleva consigo un mayor o menor riesgo: la actividad financiera es una actividad de riesgo. De una parte, cuando un particular deposita su dinero en un banco, corre el riesgo de que la entidad financiera se insolvente y no pueda retirarlo en un futuro. De otra bilidad objetiva sin atenuantes, como en el caso de la responsabilidad contractual bancaria por el pago de cheques adulterados, sobre lo cual hay abundante jurisprudencia en Colombia y, llevándose a extremo, en el caso de los daños causados en el ejercicio de la medicina, que serían atribuidos a ese riesgo profesional": M. Aramburo Calle, "Responsabilidad civil y riesgo en Colombia: apuntes para el desarrollo de la teoría del riesgo en el siglo xxI", Revista Facultad de Derecho y Ciencias Políticas Universidad Eafit de Medellín, vol. 38, n. ${ }^{\circ}$ I08, $2008,29$.

36 "All investment involves risk": Lord Nicholls, en Royal Brunei Airlines v. Tan, I995. A.C. 378. 
parte, cuando el banco otorga un crédito asume el riesgo de incumplimiento por parte del deudor. En ambos casos se trata de un riesgo de pérdida por parte del inversionista. Sin embargo, un análisis del fenómeno no puede limitarse a ese aspecto, toda vez que en materia financiera el riesgo representa una oportunidad de obtener ganancias ${ }^{37}$.

Así las cosas, existe una relación directa entre riesgo y rendimiento: entre más grande sea el riesgo, mayor deberá ser el rendimiento para que se justifique su existencia.

En este orden de ideas, y atendiendo las particularidades de la actividad financiera, actualmente nos encontramos ante una tendencia a objetivar la responsabilidad profesional de las entidades financieras por considerar que son estas quienes deben asumir los riesgos que introducen mediante la prestación de sus servicios ${ }^{3}$. Dicho esto, a continuación nos referiremos al desarrollo que ha tenido la responsabilidad de los establecimientos bancarios por el pago de cheques falsos o alterados en Colombia.

\section{Desarrollo legislativo de la responsabilidad de los establecimientos bancarios por el pago de cheques falsos o alterados en Colombia}

La regulación de la materia objeto de estudio inició en Colombia con la expedición de la Ley 46 de 1923 sobre instrumentos negociables. Si bien "Colombia ya contaba con una legislación bastante general y amplia en materia de letras de cambio, carecía de disposiciones precisas y convenientemente reglamentarias en materia de cheques"39. Debido a lo anterior, la rama legislativa vio la necesidad de expedir una ley capaz de sistematizar las relaciones jurídicas que pudieran surgir entre las partes que estuviesen involucradas en el manejo de instrumentos negociables tales como la letra de cambio, el pagaré y el cheque, entre otros.

La redacción de esta ley estuvo inspirada en las legislaciones inglesa y estadounidense sobre instrumentos negociables, quedando plasmada la responsabilidad de los bancos por el pago de cheques falsos o alterados en su artículo ig I en los siguientes términos:

38 "Pues bien, en nuestro sentir son dos las variables que han gravitado sobre la transformación de la responsabilidad profesional en los últimos años: la inclusión dentro de sus obligaciones, esto es, adicionalmente a las consagradas en el contrato, de conductas esperadas que se predican a su cargo en virtud de la ley o la jurisprudencia, como venimos de verlo[,] y la tendencia a objetivar ciertas situaciones en las cuales no solo es irrelevante la buena conducta del banco, sino que a éste no le alcanza para exonerarse de responsabilidad con probar la culpa de su cliente o, en todo caso, tal expediente, resulta totalmente excepcional”: Rodríguez Azuero, ob. cit., I 74.

39 Exposición de motivos de la Ley 46 de 1923. 
Todo banco será responsable a un depositante por el pago que aquél haga de un cheque falso o cuya cantidad se ha aumentado, salvo que dicho depositante no notifique al banco dentro de un año después de que se le devuelva el comprobante de tal pago, que el cheque así pagado era falso o que la cantidad de él se había aumentado.

Tras la expedición de esta norma la doctrina colombiana señaló que "este precepto legal [consagraba] un principio jurídicamente lógico dentro de la legislación vigente y por ende en caso de incompatibilidad con los anteriores de la misma ley 46 de 1923 o con los del Código Civil [...] estaría llamado a prevalecer en la forma en que estaba concebido y formulado, de acuerdo con las reglas de interpretación previstas en las leyes 57 y I43 de I887"40.

Sin duda, este artículo circunscribió su campo de aplicación al área de la responsabilidad contractual, de tal forma que se dio una "vinculación del depositante con el depositario"4I. Así mismo, debe mencionarse que pareciera ser que la razón por la cual se exigió que el girador notificara al banco del pago del cheque falso dentro del año siguiente a que se le devolviera el comprobante de tal pago radicó en que la omisión en esta notificación podría entenderse como una ratificación tácita del pago y por lo tanto no cabría responsabilidad en cabeza de la entidad bancaria.

Años más tarde, con la expedición del código de comercio, en I97I, esta norma fue derogada y en su lugar la materia objeto de estudio vino a ser regulada por sus artículos 732, 733 y I391, que actualmente señalan:

Artículo 732. Todo banco será responsable a un depositante por el pago que aquel haga de un cheque falso o cuya cantidad se haya aumentado, salvo que dicho depositante no notifique al banco, dentro de los tres meses después de que se le devuelva el cheque, que el título era falso o que la cantidad de él se había aumentado.

Artículo 733. El dueño de una chequera que hubiere perdido uno o más formularios y no hubiere dado aviso oportunamente al banco, sólo podrá objetar el pago si la alteración o la falsificación fueren notorias.

Artículo I39r. Todo banco es responsable con el cuentacorrentista por el pago que haga de un cheque falso o cuya cantidad se haya alterado, salvo que el cuentacorrentista haya dado lugar a ello por su culpa o la de sus dependientes, factores o representantes. La responsabilidad del banco cesará si el cuentacorrentista

4 I Ibíd., 305 . 
no le hubiere notificado sobre la falsedad o adulteración del cheque, dentro de los seis meses siguientes a la fecha en que se le envió la información sobre tal pago. Si la falsedad o alteración se debiere a culpa del librador, el banco quedará exonerado de responsabilidad.

En primer lugar, conviene señalar que los artículos 732 y г 39I hacen referencia al pago de cheques falsos que no han sido extraviados por parte del girador, mientras que el artículo 733 se centra de manera particular en el pago de cheques falsos cuyo desembolso estuvo precedido de la pérdida de los mismos ${ }^{42}$.

Parte de la doctrina ha señalado que, en relación con los artículos 732 y I39I,

... la responsabilidad del banco se extiende al pago de cualquier cheque falso o alterado, no importa que la calidad de la falsificación sea excelente. Pero puede liberarse su responsabilidad, demostrando la culpa del librador o de sus dependientes, factores o representantes. [Sin embargo,] tratándose del caso de robo o pérdida de chequera [esto es, en aplicación del artículo 733,] la ley suaviza la responsabilidad del banco, si falta el aviso oportuno del librador43.

A continuación presentaremos cuál ha sido el alcance y contenido que la jurisprudencia les ha asignado a los preceptos citados, así como el entendimiento que ha tenido sobre el particular.

\section{Desarrollo jurisprudencial de la responsabilidad de los establecimientos bancarios por el pago de cheques falsos o alterados en Colombia}

Tomando como fundamento las anteriores disposiciones legales, la Corte Suprema de Justicia, al ocuparse del régimen de responsabilidad al que se encuentran sometidos los establecimientos bancarios por el pago de cheques falsos o que han sido alterados por un tercero, ha tomado diversas posiciones, las cuales se desarrollarán a continuación.

Dichas posturas pueden agruparse cronológicamente así: (i) de I936 a I938, la Corte optó por aplicar un régimen objetivo que podría considerarse agravado; (ii) en I943, acudió a elementos subjetivos para plantear por primera vez la posibilidad de que las entidades bancarias respondieran a la luz de una respon-

42 Un sector de la doctrina sostiene que los artículos 732 y I 39I prevén hipótesis iguales debido a que ambos hacen referencia a las "relaciones de cuenta corriente entre el girador y su banco" y por lo tanto presentan contradicciones entre ellos, de tal forma que el artículo I 39 I "sería el aplicable por ser una norma especial y por ser posterior su colocación dentro del Código": G.J. Ravassa Moreno, Títulos valores nacionales e internacionales, Bogotá, 2006, 46I.

43 Ver ibíd., 46r. 
sabilidad subjetiva por culpa probada; (iii) hacia el año I964, decidió volver a su planteamiento inicial y por ende retomó los postulados de una responsabilidad objetiva que también podría considerarse agravada, aunque por razones diferentes, como se verá; (iv) en I 965, la jurisprudencia civil de la Corte regresó al campo de la responsabilidad subjetiva, pero esta vez desde una óptica de presunción de culpa; (v) de I976 a 2003, no dudó en afirmar que los bancos debían responder bajo un régimen de responsabilidad objetivo, que, además, puede considerarse agravado; y (vi) del año 2005 al año 2008 , optó por defender la tesis en virtud de la cual por regla general la responsabilidad de dichas entidades es objetiva, y también puede considerarse que agravada, salvo cuando el girador ha extraviado su chequera, evento en el cual la responsabilidad es subjetiva por culpa probada.

\section{Primera posición (1936-1938): responsabilidad objetiva}

Entre los fallos proferidos durante esta época es relevante el análisis de dos sentencias que ilustran la posición de la Corte en relación con el régimen de responsabilidad de carácter objetivo bajo el cual respondieron las entidades bancarias por el pago de cheques falsos. La Corte no planteó durante este periodo la idea de un régimen de responsabilidad objetivo, simple y llanamente, sino que fue más allá y sometió a las entidades bancarias a un régimen de responsabilidad objetiva agravada en los términos que se explicarán más adelante.

La primera de tales sentencias, de ${ }_{193} 6^{[44]}$, resolvió un pleito en el cual el establecimiento bancario pagó i 8 cheques con cargo a la cuenta corriente del demandante sin mediar autorización por parte de este. A través de un dictamen pericial se logró comprobar que la firma de los i 8 cheques no correspondía a la propia del cuentacorrentista, sino que había sido falsificada por su empleado de confianza, quien, dada la cercanía que tenía con el demandante, tomó su chequera, falsificó su firma y cobró estos cheques al establecimiento bancario. Tras un estudio detallado del caso, la Corte indicó:

El art. I9I de la ley 46 de I923 por su contexto consagra el sistema del riesgo creado: es decir, el aludido principio de que la responsabilidad por el pago de un cheque falso es el riesgo normal del comercio de banco: "todo banco será responsable a un depositante por el pago que aquél haga de un cheque falso o cuya cantidad se haya aumentado". Sin embargo, el sistema legal del riesgo creado no impide que el banco pueda exonerarse de responsabilidad demostrando una culpa, malicia, negligencia o imprudencia de parte del girador o de sus emplea-

44 Corte Suprema de Justicia, Sala de Casación Civil. Sentencia del 9 de diciembre de i936, M.P.: Antonio Rocha, xLIV, 405-4I 5. 
dos. Sólo que la carga de la prueba de esas circunstancias corresponde darla al banco 45 .

De esta manera, la Corte determinó que los perjuicios que las entidades bancarias causaren a terceros como consecuencia de la actividad riesgosa que ejercían, deben ser indemnizados por estas, al ser los sujetos que han introducido dicha actividad en la sociedad. No obstante, si el banco lograra acreditar un hecho culposo del girador o de sus empleados podría eximirse de responsabilidad.

En el litigio objeto de estudio, la Corte exoneró de responsabilidad a la entidad bancaria debido a que estimó probada la culpa del girador y afirmó que este, pudiendo verificar el saldo de su cuenta a través de los extractos bancarios que le llegaron, y cuyo contenido aceptó cuando ya se habían pagado la mayoría de los cheques, no alegó inmediatamente su inconformidad respecto del mismo.

Dos años más tarde, en ${ }_{193} 8^{[46]}$, se resolvió un caso en el cual un empleado de confianza del girador cobró al banco, mediante cheque girado en su favor, una suma de dinero aumentada en relación con la autorizada por el cuentacorrentista. Al momento de firmar el cheque, el girador observó que su empleado había dejado un espacio en blanco en el lugar destinado a escribir la cantidad en letras y así se lo hizo notar, manifestando este que ello no ofrecía ningún peligro. En el cheque que se le presentó al banco no se observaba discontinuidad alguna; su forma era perfecta y en él no existían señales de raspaduras ni enmendaduras, con lo cual resultaba evidente que se trataba de un cheque legítimo y sin tintes de falsedad.

La Corte, al analizar el artículo i9 I de la Ley 46 de i923, señaló que cuando los bancos o la industria bancaria responden por el pago de cheques falsos o cuya cantidad ha sido aumentada por un tercero, se aplica un régimen de responsabilidad objetivo con fundamento en las siguientes razones:

[En primer lugar,] los riesgos normales de un oficio son de cargo [de quien] lo ejerce cuando ello convenga socialmente[,] y ello ocurre con los bancos, cuya actividad no debe realizarse a riesgo ajeno, dado que ellos prestan no solo su propio capital sino el que los demás les han confiado temporalmente y reciben beneficios conforme a esta ley de economía política. [En segundo lugar,] existe un reconocimiento legal de la tendencia de la doctrina contemporánea a rehusar a los profesionales el beneficio de exoneración de la responsabilidad [...]. El oficio de pagar los cheques es una de sus actividades, autorizada y reglamentada por la ley, del cual han derivado un beneficio. Consecuencia de todo esto es la de que

46 Corte Suprema de Justicia, Sala de Casación Civil. Sentencia del I 5 de julio de I938, M.P.: Juan Francisco Mújica, xLvi, 724-725. 
no pueden restringir su diligencia ni substraerse de sus deberes, ni descargarse de ciertas obligaciones legales imperativas.

De lo anterior se desprende que la actividad bancaria es productiva y además debe ser ejercida por quienes tengan un conocimiento especial, esto es, se debe ejercer con cierto grado de profesionalismo. Así las cosas, se hizo una aplicación del riesgo como fundamento de esta responsabilidad objetiva que abarcó de manera conjunta las nociones de riesgo provecho y riesgo profesional.

La Corte indicó en esta providencia que para que los bancos pudieran exonerarse de responsabilidad por la hipótesis presentada anteriormente debían demostrar un hecho de la víctima de carácter culposo ${ }^{47}$. Lo anterior, debido a que no exonerarían al banco de su responsabilidad los hechos no culposos de la víctima, esto es, los imprevisibles e inevitables ${ }^{4}{ }^{8}$. De lo anterior parece claro que la Corte entendió que el girador debía actuar de manera prudente y diligente en el manejo y guarda de su chequera, so pena de tener que soportar el daño causado por el banco, lo cual incluye el debido cuidado en el diligenciamiento de los cheques. Tal y como lo expuso la Corte en esta misma ocasión:

El cliente contrae la obligación de usar la chequera con toda la prudencia necesaria, en el sentido de no hacer de sus esqueletos instrumentos negociables sino tomando todas las precauciones convenientes para que el establecimiento bancario girado no quede expuesto a un pago controvertible. Dentro de esta obli-

47 En este punto conviene hacer la siguiente reflexión: a lo largo de la sentencia, la Corte hace referencia a un régimen objetivo de responsabilidad de los bancos, en el que no interviene el concepto de culpa. Sin embargo, a renglón seguido indica que la responsabilidad "se desplaza hacia el terreno del derecho común tan pronto como se prueba culpa en el girador, y el Banco, cesa de estar obligado a reparar en tanto que una culpa no se haya establecido a su cargo". Esta afirmación parece confusa, dado que la existencia de una causa extraña, como el hecho de la víctima, no modifica el régimen de responsabilidad. Cosa distinta es que, conforme a la norma aplicada, en los casos de responsabilidad de los bancos por pago de cheques falsos o adulterados, el hecho de la víctima deba ser culposo.

48 Expresó la Corte: "La culpa del girador produce, pues, una exoneración total del riesgo, en el sentido de que ella alivia al banco completamente de la responsabilidad que pesaba sobre él, salvo en dejarle una parte de ésta en caso de culpa probada a su cargo. Ello se explica porque siendo la condición esencial para que exista la responsabilidad por riesgo la de que haya una relación de causa a efecto entre el hecho y el daño, el hecho del banco viene a ser la causa aparente del daño, en tanto que su verdadera causa reside en la culpa del girador, y el perjuicio es, por consiguiente, consecuencia de esta culpa. Desde otro punto de vista, el hecho culposo del girador del cheque debe ser extraño al banco. No es extraño cuando, por ejemplo, ese hecho ha debido ser previsto por el banco, o cuando no evitó las consecuencias nocivas, habiendo podido hacerlo. Todos los demás hechos no culposos del girador, o sea los imprevisibles e inevitables, no exoneran de su responsabilidad por riesgo al banco". Al respecto es importante señalar que, si bien la corporación afirma que "la culpa del girador produce una exoneración total del riesgo", esta afirmación también parece imprecisa, ya que no se exonera al banco del riesgo, que sigue siendo el fundamento aplicable, sino de la responsabilidad que pretende atribuírsele con base en este. 
gación de prudencia y diligencia está la de que el titular de la chequera redacte el cheque sin blancos que faciliten el abuso que un malhechor pueda cometer aumentando el monto de la suma por pagar49.

De esta manera, en el caso que fue de conocimiento de la Corte, dado que el girador no cumplió con su obligación de prudencia y diligencia al dejar espacios en blanco en el cheque, la Corte estimó que su patrimonio era el que debía soportar el daño y, por lo tanto, no casó la sentencia de segunda instancia, que exoneró de responsabilidad a la entidad bancaria.

Es dable concluir, de los fallos analizados, que de 1936 a I938 la Corte determinó que, a la luz del artículo I4I de la Ley 46 de I923, los establecimientos bancarios debían responder bajo un régimen de responsabilidad objetiva. Si bien en un principio esta corporación solo tuvo en cuenta el riesgo creado como fundamento de este régimen de responsabilidad, en esta época decidió dar aplicación a otras variantes del riesgo: el riesgo provecho o beneficio y el riesgo profesional. Esto muestra, en materia de riesgo, que hubo cierta evolución, puesto que el riesgo provecho o beneficio puede entenderse como un complemento del riesgo creado y del riesgo profesional.

En cuanto a las causales de exoneración, cabe mencionar que la Corte fue fiel a su posición de exigir al banco la prueba de un hecho culposo de la víctima, con lo cual podría entenderse que se optó por un régimen de responsabilidad objetivo agravado. De no haber sido así, la demostración de una simple causa extraña, y no de una de carácter culposo, le habría permitido al banco exonerarse de responsabilidad.

\section{Segunda posición (I943): responsabilidad subjetiva por culpa probada}

La Corte, en $1943^{\left[5^{\circ}\right]}$, dilucidó una controversia que se presentó entre un banco y una persona natural que habían celebrado un contrato de cuenta corriente. El objeto de la discusión se circunscribió al pago de cuatro cheques falsos que el banco había realizado con cargo a la cuenta del girador y respecto de los cuales este nunca había prestado su consentimiento. En el proceso se probó que quien había diligenciado dichos cheques y los había cobrado al banco había igualmente falsificado la firma del girador.

Contrario a lo que había concluido en años anteriores con respecto a la responsabilidad de los establecimientos bancarios por el pago de cheques falsos, en esta oportunidad, tras un análisis del caso y el estudio de la Ley 46 de I923,

49 Corte Suprema de Justicia, Sala de Casación Civil. Sentencia del I 5 de julio de i938, M.P.: Juan Francisco Mújica, XLVI, 724-725.

50 Corte Suprema de Justicia, Sala de Casación Civil. Sentencia del I I de marzo de i943, M.P.: Isaías Cepeda, Lv, 48-52. 
la Corte concluyó que en la medida en que los cheques son instrumentos negociables y sus firmas se presumen auténticas, quien alegue su falsedad deberá acreditarla. La Corte, además, consideró que la responsabilidad de los bancos se funda en la culpa; en efecto, señaló que el fundamento de responsabilidad del artículo i9 I de la Ley 46 de I923

No [podría] ser otro que la obligación de cuidado que corresponde a los Bancos para defender el dinero que sus clientes les confían, mediante el control que pueden y deben ejercitar con relación a la identidad de la firma de sus consignatarios, ya sea para obtener chequeras, ya para el pago de sus cheques. Este aspecto fundamental de la responsabilidad bancaria, vinculado a la demostración de una culpa por descuido o negligencia en el control del uso de la firma de los clientes, es cuestión de hecho que en cada caso hará variar el concepto de la responsabilidad y su alcance ${ }^{5}$.

En este caso, si bien el demandante logró comprobar que su firma había sido falsificada, la parte demandada también acreditó que el girador había incurrido en culpa al momento de aceptar que, tras haberse pagado dos de los cuatro cheques falsos, el saldo que de su cuenta aparecía en su extracto bancario era el correcto.

En consecuencia, en términos de la Corte, concurrieron las culpas de ambas partes y por ende se condenó al banco al reembolso de los dos cheques que se pagaron con posteridad a la aceptación del extracto bancario enunciado anteriormente. Creemos que en estricto sentido, más allá de una reducción en la condena por concurrencia, ocurrió una exoneración total respecto de una parte del daño, esto es, el referido a los dos cheques cuyo pago constaba en los extractos.

Si bien el planteamiento de una responsabilidad subjetiva con fundamento en la culpa probada no tuvo acogida en los años siguientes, sí fue una muestra de los tintes de subjetividad que nuestra jurisprudencia intentó aplicar en esta materia.

\section{Tercera posición (1964): responsabilidad objetiva agravada}

En I $964^{\left[5^{2}\right]}$, la Corte resolvió un litigio en el cual una entidad bancaria fue demandada debido a que pagó 20 cheques cuya firma había sido falsificada por parte de un empleado de la sociedad demandante con cargo a la cuenta corriente de dicha entidad. Al momento de la apertura de la cuenta quedó claro ante el banco que la única persona facultada para suscribir cheques era el gerente de la persona jurídica titular y por ende su firma quedó registrada. Sin embargo, la

5 Ibíd., 48-52.

52 Corte Suprema de Justicia, Sala de Casación Civil. Sentencia del 7 de abril de i 964, M.P.: Julián Uribe Cadavid. 
entidad bancaria, al momento del pago de los cheques, no se dio cuenta de que la firma que aparecía al pie de los mismos no coincidía con aquella que había sido registrada y, sin ningún reparo, desembolsó el dinero.

Quedó probado en el proceso, además de la falsedad de la firma en el cheque, que la sociedad extravió y no leyó los extractos de cuenta que fueron enviados por el banco y que quien cometió el ilícito fue un empleado de la sociedad que tenía acceso a las chequeras de esta. Con lo anterior, para la Corte quedó claro que la entidad demandante había incurrido en culpa por negligencia o descuido en la custodia de sus chequeras.

Tras analizar el artículo i9 I de la Ley 46 de i993, en concordancia con los artículos 63 y r604 c. c., la Corte consideró que en esta norma existía una presunción de culpa en cabeza del banco, a quien, para romperla y por ende exonerarse de responsabilidad, no le bastaba probar que el daño había ocurrido debido a un caso fortuito o fuerza mayor, sino que, además, debía demostrar que había actuado con la diligencia y el cuidado debidos 53 .

Si bien lo anterior podría implicar que la Corte planteó que se trataba de una responsabilidad subjetiva por culpa presunta, en el fondo, al exigirle al banco la prueba de caso fortuito o fuerza mayor para exonerarse, aplicó lo propio de un régimen objetivo que únicamente permite exonerar de responsabilidad al demandado por medio de una causa extraña. Si se hubiese tratado de un régimen subjetivo de culpa presunta, no habría duda de que el demandado habría podido exonerarse probando uno de dos elementos: diligencia en su actuación o concurrencia de una causa extraña. No obstante, de lo señalado por la Corte se deduce que la prueba de ambos hechos resultaba necesaria.

De esta manera puede pensarse que se aplicó un régimen objetivo agravado, en la medida en que se le exigía al banco que demostrara, a más de que el daño ocurrió por un caso fortuito o fuerza mayor, que actuó con el cuidado y la diligencia necesarios en el desarrollo de su actividad.

Al momento de fallar, la Corte halló responsable al banco, pero, avalando la sentencia de segunda instancia, absolvió al banco del pago de las tres cuartas partes del valor total de los cheques falsos debido a que encontró probada culpa en cabeza de la sociedad demandante.

53 Expresó la Corte: "El hecho de pagar cheques falsos implica para el Banco girado una presunción de culpa, como aparece claramente de lo dispuesto por el artículo ig I de la ley 46 de I923, en acuerdo con los artículos I 604 y 63 del Código Civil. Y para que quien hizo esos pagos pueda exonerarse de la culpa es necesario que destruya la presunción [...]. Hay una presunción de culpa en quien no las satisface [las obligaciones] en el modo y tiempo debidos, porque el incumplimiento es un hecho o una omisión que afecta el derecho ajeno. El deudor puede destruir esa presunción probando que su incumplimiento obedeció a fuerza mayor o caso fortuito que sobrevino sin culpa[,] pero como la culpa proviene de no obrar con la diligencia o cuidado que la ley gradúa según la naturaleza del contrato (arts. 63 y I604), resulta que al deudor, para exonerarse de responsabilidad, no le basta probar el caso fortuito, sino también que empleó la diligencia, o cuidado debido para hacer posible la ejecución de su obligación". 


\section{Cuarta posición (1965): responsabilidad subjetiva por culpa presunta}

En $1965^{[54]}$, la Corte precisó sus afirmaciones de 1964, para dar aplicación a un verdadero régimen de responsabilidad de culpa presunta. Así, resolvió un caso en el cual se demandó a una entidad bancaria por haber pagado dos cheques aparentemente falsos con cargo a la cuenta corriente de la sociedad demandada. Los cheques objeto del proceso habían sido hurtados por un tercero, quien, al momento de diligenciarlos, incluyó un sello que no se encontraba registrado en el banco. Tras revisar el caso e interpretar el artículo i9i de la Ley 46 de 1923 , la Corte manifestó:

De una vez resalta la naturaleza contractual de la responsabilidad sentada por la norma cuando contempla al depositante en cuenta bancaria que se mueve por cheques y consignaciones expresadas en dinero, o sea con la fisonomía básica contractual del depósito irregular, de acuerdo con el artículo 2246 del Código Civil. La responsabilidad [del] establecimiento de crédito se presume por el pago de cheques falsos o cuya cantidad se haya aumentado, no porque a través del riesgo de empresa se consagre allí el criterio objetivo ajeno al derecho colombiano, sino porque probado el antecedente necesario de la adulteración del cheque, pesa sobre el banco que lo ha cubierto la carga de acreditar que su conducta estuvo conforme con las reglas profesionales de cuidado, prudencia y diligencia para descubrir el fraude y prevenirlo.

De igual forma, la Corte calificó la relación contractual que existía entre el banco y el cuentacorrentista como una relación de confianza en virtud de la cual debía existir una "reciprocidad de esfuerzos en la tarea de evitar el daño que se desprende de la emisión de cheques falsos" 55 . Lo anterior implica que no solo el banco debió actuar de manera diligente y precavida al momento de pagar los cheques que se le cobraron, sino también que el titular de la cuenta corriente debió obrar de la misma manera en la custodia de su chequera ${ }^{5}$.

Todo lo anterior llevó a la corporación a concluir que, a la luz de la Ley 46 de 1923 , los bancos debían responder por el pago de cheques falsos o alterados con fundamento en un régimen subjetivo de culpa presunta. En ese sentido, para liberar su responsabilidad, las entidades bancarias podían acreditar que actuaron

54 Corte Suprema de Justicia, Sala de Casación Civil. Sentencia del 26 de noviembre de 1965 , M.P.: Aníbal Cardoso Gaitán.

55 Ibíd.

${ }_{5} 6$ Sobre el punto, afirmó la Corte: "El recibo de la chequera y del formulario para solicitar nueva provisión de cheques, implica para el cliente la obligación de custodiar los cheques y formularios de modo que ninguna otra persona pueda hacer uso de ellos y por lo tanto asume el riesgo ante el banco y ante terceros por cualquier uso indebido que de ellos se haga a causa de negligencia o descuido en la obligación de custodia que adquiere". 
con cuidado, diligencia o prudencia o que el daño ocurrió debido a cualquier otra causa exonerativa 57 .

En el caso objeto de estudio, el banco logró probar que los cheques tenían una apariencia regular en su forma exterior, de tal forma que no era posible descubrir que se trataba de cheques falsos. Adicional a ello, comprobó que "la presencia de un sello no registrado era incapaz de comprometer la regularidad exterior del documento" ${ }^{8}$ y que, en definitiva, la sociedad demandante había incurrido en un error de conducta en la guarda de la chequera que se le había suministrado. De no haber sido así, los cheques no habrían sido hurtados. Así las cosas, la Corte no casó la sentencia de segunda instancia, que había exonerado de responsabilidad a la entidad bancaria demandada.

\section{Quinta posición (1976-2003): responsabilidad objetiva agravada}

A partir de este momento es importante tener en cuenta que, dada la expedición del código de comercio en el año I97 I, la Corte emitió sus fallos aplicando la regulación establecida en el nuevo estatuto mercantil y por ende dejó a un lado la Ley 46 de 1923.

Con el paso del tiempo y tomando como punto de referencia la actividad que desarrollan los bancos y el beneficio directo que ellos reciben como consecuencia de la misma, la Corte profirió tres sentencias en las cuales es posible observar el regreso al riesgo creado y el riesgo beneficio como fundamentos de la responsabilidad objetiva a la que se sometió a los bancos por el pago de cheques falsos o cuya cantidad ha sido aumentada por un tercero.

La primera de ellas, del año i $976^{[59]}$, resolvió un caso en el cual una entidad pagó un cheque falso con cargo a la cuenta corriente de la parte demandante, quien se había comportado de manera prudente y diligente en el manejo y custodia de su chequera. Interpretando el artículo r 39 I c. de co., la Corte estableció que "la medida de responsabilidad de un banco por el pago de cheque falso no se detiene en la culpa, sino que alcanza el riesgo creado. [De esta manera, para que el banco pueda exonerarse de responsabilidad,] no le basta el lleno de las precauciones habituales, sino que es preciso probar algún género de culpa en el titular de la cuenta corriente" 60 .

57 Afirmó: "Pesa sobre el banco la carga de acreditar que su conducta estuvo conforme con las reglas profesionales de cuidado, prudencia y diligencia [...]. [Sin embargo, también] está capacitado para liberarse si prueba causas exonerativas, como puede serlo el incumplimiento del depositante en lo que respecta a su obligación primordial de custodiar la chequera".

58 Corte Suprema de Justicia, Sala de Casación Civil. Sentencia del 26 de noviembre de I965, M.P.: Aníbal Cardoso Gaitán.

59 Corte Suprema de Justicia, Sala de Casación Civil. Sentencia del 29 de noviembre de I976, M.P.: Humberto Murcia Ballén, cLII, 522-ıo6.

6 Ibíd., 522-106. 
Así, dado que el banco no logró probar que el demandante había actuado de manera culposa, la Corte estimó que aquel debía responder por los perjuicios causados al girador ${ }^{6}$.

Años más tarde, en $1994^{[62]}$, la Corte conoció de un pleito en el cual un banco había pagado cuatro cheques falsos con cargo a la cuenta corriente de la sociedad demandante. Al momento de la apertura de la cuenta se pactó con el banco que todos los cheques que se fueran a cobrar debían estar suscritos por dos personas cuyas firmas habían quedado registradas para los controles correspondientes. La entidad bancaria pagó los cheques mencionados aun cuando una de las firmas requeridas había sido falsificada. En un estudio juicioso del caso, la Corte señaló:

El problema de quién debe soportar el daño derivado del cheque falso lo resuelve el inciso primero del artículo r39 I del Código de Comercio, el cual establece que "todo banco es responsable con el cuentacorrentista por el pago que haga de un cheque falso o cuya cantidad se haya alterado, salvo que el cuentacorrentista haya dado lugar a ello por su culpa o la de sus dependientes, factores o representantes”, precepto que a su vez guarda armonía con el texto del artículo 732 del mismo cuerpo legal. Si no hubo culpa del cuentahabiente, el Banco responde, así tampoco haya existido culpa de su parte, en aplicación del citado inciso, que refleja los principios generales del derecho de obligaciones ${ }^{6}{ }^{3}$.

Como fundamento de lo anterior, la Corte señaló que, en atención a las operaciones que realizan las entidades bancarias, estas están en capacidad de soportar los daños que causan a sus giradores con el pago de cheques falsos o cuya cantidad ha sido aumentada por un tercero. Dicho de otro modo, los bancos deben responder objetivamente por este tipo de daños, dado el riesgo que crean en la sociedad con el ejercicio de su actividad y los beneficios directos que de ello perciben ${ }^{6}$. No obstante, al estudiar el punto relativo a la exención de responsabilidad, la Corte señaló que, de conformidad con la norma objeto de análisis, los bancos solamente dejarían de ser responsables en la medida en que demostraran

6 I "El banco no acreditó en el proceso que hubiese existido culpa del cuentacorrentista en la falsificación del cheque [y por lo tanto] la responsabilidad por el pago de dicho instrumento corresponde al librado".

62 Corte Suprema de Justicia, Sala de Casación Civil. Sentencia del 24 de octubre de i994, exp. $435^{2}$.

63 Ibíd.

64 "Conviene insistir una vez más en que el citado artículo r 39 I del Código de Comercio establece quién debe correr con los riesgos de los cheques falsificados, riesgo impuesto por la ley a las entidades financieras quienes, dado el volumen de transacciones que realizan, compensan las pérdidas que los cheques falsificados pueden causar, regla esta que tiene como obvia excepción que la culpa de los hechos recaiga en el cuentacorrentista o en sus dependientes, factores o representantes". 
culpa en cabeza del girador o sus dependientes. Lo anterior podría implicar que se trata de un requisito que agrava la responsabilidad, en la medida en que no permite la exoneración del banco con la simple acreditación de una causa extraña, culposa o no, como sucedería por regla general en un régimen de responsabilidad objetiva.

En el año 200 I $^{[65]}$, la Corte resolvió un caso en el cual la sociedad demandante, tras haber extraviado su chequera, observó que el banco con el cual había celebrado su contrato de cuenta corriente había pagado cuatro cheques falsos con cargo a su cuenta. Siguiendo lo expuesto en la sentencia de I994, la Corte aseveró:

Del contexto [del artículo I 39 I del Código de Comercio] se colige que la responsabilidad que se atribuye al banco deriva del ejercicio y el beneficio que reporta de su especializada actividad financiera, [en virtud de la cual] asume los riesgos inherentes a la organización y ejecución del servicio de caja [y cuya] responsabilidad sería resultante del hecho del pago de un cheque con firma falsificada o adulterado. Sin embargo, este riguroso principio se quiebra si por culpa del cuentacorrentista, de sus dependientes, factores o representantes, se dio lugar al pago del cheque con firma falsificada, o alterado, cesando así la responsabilidad para el banco en el caso de no haber sido noticiado por el cuentacorrentista sobre la falsedad o adulteración del cheque dentro de los seis meses siguientes a la fecha en que se le envió la información sobre tal pago; en el evento de no haber dado oportuno aviso al banco, se restringe la posibilidad al cuentacorrentista de objetar el pago, al hecho de que la alteración o falsificación fueren notorias (art. 733 C. de Co.).

El primer comentario que merece el extracto anterior, ya que no fue precisado por la Corte, es que el artículo 733 c. de co. solo tiene aplicación en los eventos en los cuales el pago de un cheque falso se encuentre antecedido de la pérdida de la chequera por culpa del girador y dicha pérdida no haya sido notificada al banco de manera oportuna. Únicamente en estos eventos, la posibilidad que tiene el titular de la chequera de objetar el pago de un cheque falso se restringe a la falsedad o alteración notoria del cheque.

La Corte no casó la sentencia proferida en segunda instancia y señaló que, dado que la chequera se había extraviado por culpa del librador sin que este hubiese dado aviso oportuno al banco, y que la falsedad del cheque no era notoria, el banco debía ser exonerado de responsabilidad, según lo establecido en el citado artículo 733 .

De las sentencias analizadas durante este periodo es dable concluir que, con la entrada en vigencia del código de comercio, la Corte planteó primeramente

65 Corte Suprema de Justicia, Sala de Casación Civil. Sentencia del 3 I de julio de 200 I, exp. 583 I. 
que la responsabilidad por el pago de cheques falsos o alterados debía regirse, a manera de regla general, por el artículo i 39 I y a la luz de una responsabilidad objetiva (agravada), en los términos expuestos anteriormente. De igual forma, si bien con el código de comercio la Corte encontró que existía una disposición particular para los casos en los cuales el girador hubiese perdido su chequera (art. 733), guardó silencio en cuanto al régimen de responsabilidad aplicable a dicho tipo de eventos.

\section{Sexta posición (2005-20o8): responsabilidad objetiva agravada, salvo cuando el girador haya extraviado su chequera, evento en el cual la responsabilidad es subjetiva por culpa probada}

Durante este periodo de tiempo la Corte profirió cuatro sentencias en las cuales es posible analizar y diferenciar los regímenes de responsabilidad que serían aplicables según los eventos de pago de cheques falsos o alterados expuestos por el código de comercio, esto es, (i) pagos antecedidos de la pérdida de la chequera por parte del girador (art. 733 c. de co.) y (ii) pagos en los cuales lo anterior no ocurrió (arts. 732 y i 39 I c. de co.).

En la primero de los fallos en comento, del año $2005^{[66]}$, la Corte dilucidó la polémica que se presentó entre una persona jurídica y su banco, con quien había celebrado un contrato de cuenta corriente, debido a que este pagó un cheque falso. Se probó que las firmas con las cuales se debían suscribir los cheques habían sido falsificadas por terceros y que el girador había extraviado el cheque. $\mathrm{Al}$ momento de fallar, la Corte explicó que, según el artículo 733 c. de co., para que el banco sea declarado responsable por el pago de un cheque falso o adulterado que se ha producido tras haber sido extraviado, el girador tiene la carga de probar, además del aviso oportuno de esta pérdida al banco, que la falsedad de este instrumento era notoria o "burda y por ende apreciable sin esfuerzo"67. De igual forma, precisó:

66 Corte Suprema de Justicia, Sala de Casación Civil. Sentencia del I 5 de julio de 2005, M.P.: Jaime Alberto Arrubla.

67 Teniendo en cuenta la literalidad del artículo en comento, pareciera ser que la Corte con esta interpretación desconoció el contenido del mismo. Una interpretación exegética del artículo 733 llevaría a concluir que el banco solo es responsable cuando, frente a la pérdida de uno o más cheques y la ausencia del aviso oportuno de esta pérdida al banco, el cuentacorrentista logra demostrar la falsedad notoria del instrumento y no, como lo expuso la Corte, que el banco responde cuando el cuentacorrentista pruebe una de dos situaciones: que avisó de manera oportuna al banco acerca de la pérdida del cheque o que la falsificación era notoria. Lo anterior encuentra su razón de ser en el hecho de que la restricción que trae el artículo 733, en punto de limitar la objeción del pago de uno o varios cheques adulterados a la falsedad notoria de los mismos, es una hipótesis que está condicionada al hecho de haberlos extraviado y no haber notificado al banco de esta situación oportunamente. 
El establecimiento bancario no tiene la carga de demostrar la culpa del cuentacorrentista en la pérdida del esqueleto o esqueletos del cheque, ya que ello sería exigir la satisfacción de un requisito que la ley no prevé, pues, el tratamiento particular que ofrece el citado artículo 733 parte de la simple y llana pérdida, seguida, eso sí, de la falta de enteramiento al banco o del anuncio extemporáneo.

En virtud de lo anterior, la Corte condenó al banco, debido a que el girador cumplió con su carga probatoria. Ahora bien, en cuanto al régimen de responsabilidad aplicable al artículo 733, si bien la Corte no lo señaló de manera expresa, podría inferirse, a partir de la distribución de cargas probatorias explicada anteriormente, que se trató de un régimen de responsabilidad de culpa probada. En efecto, si el demandante, es decir, el titular de la chequera, debe probar el carácter notorio de la falsedad, de ello puede inferirse que debe probar la culpa del banco para objetar el pago, puesto que una falsedad notoria no advertida por este da cuenta de su falta de diligencia.

Un año después, en $2006^{[68]}$, la Corte resolvió un litigio en el cual la sociedad demandante alegó que la entidad bancaria, con la cual había celebrado contrato de cuenta corriente, pagó dos cheques de manera irregular con cargo a su cuenta. Se logró comprobar que la sociedad extravió su chequera y que el banco solo tuvo conocimiento de este hecho una vez se inició el juicio de responsabilidad. La Corte, al interpretar el artículo 733, adoptó lo que se había planteado en la sentencia del año 2005 , expuesta anteriormente ${ }^{69}$, citando la misma en los siguientes términos: "En la hipótesis regulada por el artículo 733 del Código de comercio, sin importar que la pérdida del instrumento haya sido culposa o no, se invierte la regla de la responsabilidad a cargo del librado que se adopta en las disposiciones anteriores, para imponérsela al cliente".

De este modo y manteniendo su línea de pensamiento, la Corte reconoció que, tratándose del evento regulado en el artículo 733, el régimen de responsabilidad aplicable debía ser distinto al que ya se había fijado para los supuestos de hecho contemplados por los artículos 732 y i93 I c. de co. (objetivo y, según el entendimiento hecho de él en este artículo, agravado). Así las cosas, mantuvo su posición en el sentido de aplicar un régimen de responsabilidad subjetivo de culpa probada en los casos en los que el girador hubiere extraviado su cheque$\mathrm{ra}^{70}$. Al momento de fallar, la Corte no casó la sentencia de segunda instancia $y$, por ende, el banco fue exonerado de responsabilidad, debido a que la parte

68 Corte Suprema de Justicia, Sala de Casación Civil. Sentencia del 29 de septiembre de 2006, exp. I IOOI-3IO3-OI9-I992-20I39-OI.

69 Corte Suprema de Justicia, Sala de Casación Civil. Sentencia del 15 de junio de 2005, M.P.: Jaime Alberto Arrubla.

70 De igual forma, siguiendo lo expuesto en la sentencia del año 2005 , la Corte señaló que la entidad bancaria no tiene que probar culpa del cuentacorrentista en la pérdida de la chequera ya que esto implicaría la exigencia de un requisito no previsto por la ley. 
demandante no logró acreditar que hubiera dado aviso oportuno de la pérdida del cheque o que la falsedad hubiese sido notoria. En palabras de la Corte, lo anterior "brilló por su ausencia en el proceso".

Finalizando el año $2006^{[71]}$, la Corte falló un caso en el cual la entidad bancaria demandada transfirió fondos de la cuenta del demandante en favor de un tercero, teniendo como fundamento una solicitud escrita cuyas firmas y sellos habían sido falsificados. Si bien esta hipótesis no contemplaba el pago de un cheque falso, la Corte aplicó el artículo r 39 I con fundamento en lo siguiente:

Es evidente que la norma contenida en el citado artículo I39I del estatuto mercantil, que en principio fue destinada a regular lo atinente a la responsabilidad del banco librado por el pago de un cheque falso o cuya cantidad se haya alterado, no contempla expresamente el evento de la falsedad de una nota débito o cualquiera otra forma alternativa de disposición de los fondos depositados en la cuenta corriente bancaria respectiva. Con todo, ello no implica que con miras a establecer la responsabilidad contractual del banco emanada del pago de una nota débito materialmente alterada o la ausencia de esa responsabilidad, si es que fue el proceder del cuentacorrentista el factor determinante de la defraudación, el juzgador no pueda aplicar las pautas previstas en la señalada disposición.

En cuanto al régimen de responsabilidad contenido en este artículo, la Corte señaló que, dada la calidad que tienen las entidades bancarias (comerciantes expertos en la intermediación financiera) y la confianza colectiva que en ellas se deposita, "la diligencia exigible no es apenas la de un buen padre de familia, sino la que corresponde a un profesional que deriva provecho económico de un servicio que compromete el ahorro privado y en el que existe un interés público" . De igual forma, reiteró que el rigor de esta doctrina radica en el hecho de que son los bancos quienes tienen que asumir los riesgos de la falsificación y que dicha imputación de responsabilidad solo se puede romper si "concurre $7^{72}$ culpa imputable al titular de la cuenta corriente".

De lo anterior se desprende que la Corte estimó conveniente que, a la luz de este artículo, los bancos respondan con base en un régimen de responsabilidad objetiva, con fundamento en el riesgo profesional, régimen que en nuestra opinión resulta ser agravado, en la medida en que se exige al banco, para su exoneración de responsabilidad, la prueba de que concurre culpa del girador.

7 I Corte Suprema de Justicia, Sala de Casación Civil. Sentencia del i 5 de diciembre de 2006, M.P.: Pedro Octavio Munar.

72 El empleo del vocablo 'concurrir' nos haría creer que el banco, para exonerarse de responsabilidad, debe acreditar, además de una causa extraña, una culpa en cabeza del cuentacorrentista; situación que pareciera agravar el régimen de responsabilidad objetivo impuesto. 
En el presente caso, la Corte concluyó que la sociedad demandante incurrió en culpa, debido a que no fue cuidosa en la custodia de los sellos que debían acompañar todas las autorizaciones para la disposición de los fondos de su cuenta, pero también que el banco no cumplió con sus obligaciones, puesto que dejó pasar por alto la falsedad de las firmas y los sellos contenidos en el escrito que le fue entregado. Con base en lo anterior, la Corte redujo la condena del banco en un $30 \%$. Este fallo, en nuestra opinión, presenta algunas inconsistencias, debido a que si bien la Corte parece seguir optando por la aplicación de un régimen de responsabilidad objetiva, con fundamento en el riesgo profesional, tuvo en cuenta, al momento de fallar, el cuidado y la diligencia con que deben obrar los bancos. Siendo respetuosos de un verdadero régimen de responsabilidad objetiva, la culpa no debió ser tema de estudio y análisis.

Por otro lado, en el año $2008^{[73]}$, la Corte resolvió un caso en el cual un banco fue demandado por haber pagado un cheque cuya firma había sido falsificada, con cargo a la cuenta corriente de la parte demandante y el cual había sido previamente hurtado por parte de uno de sus empleados. Tras analizar el artículo 733 c. de co., la Corte reiteró que "la ausencia de notoriedad de la falsedad del título [tiene la capacidad de] liberar al banco demandado de la responsabilidad por el pago de cheque espurio, presupuesto de exoneración que exige la norma cuando se trata del evento en el cual el cuentacorrentista no dio aviso oportuno de la pérdida del título".

En el presente caso, y en concordancia con lo anterior, dado que la parte demandante no pudo probar la notoriedad de la falsedad del cheque, la Corte exoneró de responsabilidad al banco.

De todo lo anterior es posible inferir que esta corporación se mantuvo fiel a la posición que ya había establecido, pues reiteró que, tratándose del artículo 733 , el régimen de responsabilidad aplicable era de carácter subjetivo y con fundamento en la culpa probada.

\section{Conclusiones}

En el marco de la intervención del Estado en la economía ha de resaltarse la importancia que tienen los esquemas regulatorios en el sector financiero en busca de la protección del consumidor financiero por medio de mecanismos que permiten balancear una relación por antonomasia desequilibrada. Así pues, la creación de regímenes de responsabilidad objetiva pretende beneficiar a los consumidores al eliminar obstáculos en el resarcimiento de los perjuicios ocasionados en el seno de sus relaciones contractuales con los establecimientos bancarios, en particular frente al pago de cheques falsos o alterados.

73 Corte Suprema de Justicia, Sala de Casación Civil. Sentencia del r6 de junio de 2008, exp. I IOOI-3IO3-007-I995-0I394-OI. 
Con respecto a este supuesto en particular, el abandono de la culpa y el acogimiento del riesgo como fundamento de responsabilidad no ha sido un cambio pacífico. En efecto, la debida diligencia de los establecimientos bancarios en el ofrecimiento de productos y servicios sigue siendo uno de los principios rectores del régimen de protección al consumidor financiero, lo cual conlleva necesariamente que el análisis de su responsabilidad deba necesariamente partir del concepto de culpa. Ha de recordarse que en el marco de la responsabilidad contractual el daño proviene de la inejecución de obligaciones por parte del contratante, dentro de las cuales se encuentra aquella consistente en prestar productos y servicios con estándares de seguridad y calidad, obligación que implica la elaboración de un perfil transaccional del cliente.

Si bien la reticencia a aceptar la existencia de un régimen objetivo de responsabilidad en Colombia ha llevado a la Corte Suprema de Justicia a presentar planteamientos que contienen imprecisiones conceptuales al momento de sustentar el régimen de responsabilidad aplicable en los casos en que se debate sobre la responsabilidad de los establecimientos bancarios por el pago de cheques falsos o alterados, en el fondo, llámese como se llame, se ha tratado de un régimen que prescinde de la culpa para su estructuración. Lo que en el plano real importa, y por lo que el derecho debe promover, es la efectiva satisfacción del interés de la víctima, que se materializa en la declaratoria de responsabilidad de quien tiene una posición de superioridad negocial y quien ha introducido en la esfera social, al desarrollar una actividad que lo beneficia, un riesgo por el cual ha de responder; siempre propiciando un escenario libre de trabas y obstáculos innecesarios para quien pretende iniciar un juicio de responsabilidad.

En este orden de ideas, en Colombia se ha presentado una evolución legislativa frente a la responsabilidad de los establecimientos bancarios por el pago de cheques falsos o alterados que inicia con la expedición de la Ley 46 de I923, donde simplemente se explicitó que dichas entidades deberían responder por el pago de cheques falsos o cuya cantidad hubiere sido aumentada. Dicha norma no planteaba un régimen particular de responsabilidad, pues se limitaba a señalar que los establecimientos bancarios debían responder por los perjuicios causados con ocasión a la conducta descrita. Sin embargo, la jurisprudencia fundamentó dicho régimen de responsabilidad en el riesgo introducido por el establecimiento bancario, lo cual configuró el primer paso hacia un régimen de responsabilidad.

Dicha norma fue derogada por el código de comercio de I97 I, donde se distinguió entre el pago de cheques falsos o alterados que hubieren sido extraviados por el girador, y el pago de dichos títulos cuando no hubieren sido extraviados. Sobre el alcance de las normas del código de comercio al respecto se ha pronunciado la jurisprudencia nacional en múltiples y variadas ocasiones, integrando su contenido.

En este contexto, es oportuno recordar que la jurisprudencia de la Corte Suprema de Justicia, desde la década de I930, ha oscilado entre un régimen 
objetivo y uno subjetivo de responsabilidad al momento de analizar y fallar los casos relacionados con el pago de cheques falsos o alterados. Pese a lo anterior, es preciso poner de presente que en los casos en los cuales esta corporación ha optado por la aplicación de un régimen de responsabilidad objetivo ha acudido a elementos que, de acuerdo con nuestro análisis, han agravado el grado de responsabilidad que existe en cabeza de los bancos y por ende han dificultado su camino frente a la posibilidad de exonerarse en un eventual juicio de responsabilidad. Si bien lo anterior puede entenderse como un mecanismo de protección en favor del consumidor financiero, como parte débil de esta relación, es sin duda una muestra de la severidad con la cual nuestra jurisprudencia ha estudiado y analizado la conducta de los bancos cuando estos, siendo agentes profesionales en el mercado, han causado un daño a sus clientes. En contraposición a lo anterior, cuando la Corte ha intentado atenuar el rigor en su análisis, ha optado por acudir a la aplicación de regímenes subjetivos de responsabilidad bajo el argumento de que se debe promover una reciprocidad de esfuerzos, entre el banco y el cuentacorrentista, en aras de evitar la ocurrencia de un daño. En otras palabras, se ha tendido a exigir al girador cierto grado de cuidado y diligencia en el manejo de sus cheques.

La oscilación que ha existido, en los términos expuestos a lo largo de esta investigación, en cuanto a la posición que ha adoptado la Corte al momento de establecer el régimen de responsabilidad aplicable a los casos de pagos de cheques falsos o alterados, es sin duda una muestra de la poca claridad que siempre se ha presentado en nuestra jurisdicción en cuanto al tema. Sin embargo, parece ser que con la expedición del código de comercio esta materia ha venido adquiriendo cierta estabilidad, en la medida en que los magistrados de esta corporación han estado de acuerdo en plantear que, por regla general, la responsabilidad de los bancos por el pago de cheques falsos es objetiva y, según nuestro entendimiento, agravada, salvo cuando el girador ha extraviado su chequera, evento en el cual la responsabilidad es subjetiva basada en la culpa probada. De esta manera, aunque actualmente se busca darle protección al cuentacorrentista, mediante la aplicación de un régimen objetivo (agravado) de responsabilidad como regla general, no se ha logrado unificar esta posición respecto de todas las hipótesis de pago de cheques falsos o de cheques que han sido alterados por un tercero.

En el caso que nos ocupa, la expedición de una chequera como medio de pago implica la introducción de un riesgo en la sociedad, por cuya ocurrencia la entidad financiera ha de responder, situación que ha sido reconocida de manera expresa por el legislador. Es esta situación fáctica diferenciadora la que amerita que se aplique un régimen de responsabilidad objetivo. Es curioso que, por un lado, nos encontremos frente a una tendencia a extender el régimen de responsabilidad objetivo de los establecimientos bancarios por el pago de cheques falsos o alterados a otras situaciones que no gozan de un soporte legal que lo permita, con el fin de proteger de mejor manera al consumidor financiero de 
los perjuicios que pueda sufrir por el incumplimiento de las obligaciones de la entidad financiera, y que, por otro lado, la jurisprudencia nacional presente una reticencia frente al planteamiento de un régimen de responsabilidad por el pago de cheques falsos o alterados que no tiene en cuenta el elemento de la culpa como fundamento.

Consideramos que nos encontramos frente a un régimen de responsabilidad que se fundamenta en el riesgo profesional introducido por los establecimientos bancarios con la puesta en circulación de cheques que pueden ser objeto de alteración o falsificación, y por cuyos perjuicios han de responder sin importar el grado de diligencia empleado. En efecto, la sola introducción del riesgo es suficiente justificación para que sea el establecimiento bancario quien deba asumir la responsabilidad por la realización de dicho riesgo, máxime cuando se trata de la parte fuerte de la relación asimétrica con el consumidor financiero. En este orden de ideas, consideramos oportuno que la jurisprudencia consolide una posición sobre el particular, abogando por un régimen de responsabilidad objetiva por el pago de cheques falsos o alterados.

\section{Bibliografía}

\section{Doctrina}

Aramburo Calle, Maximiliano A. "Responsabilidad civil y riesgo en Colombia: apuntes para el desarrollo de la teoría del riesgo en el siglo xxI", Revista Facultad de Derecho y Ciencias Políticas Universidad Eafit, vol. 38, n. ${ }^{\circ}$ I08, 2008, 29 .

Bianca, Massimo. Derecho civil. El contrato, trads. F. Hinestrosa y É. Cortés, Bogotá, Universidad Externado de Colombia, 2007.

Chamie, Jose Félix. "Principios, derechos y deberes en el derecho colombiano de protección al consumidor", Revista de Derecho Privado, Universidad Externado, n. ${ }^{\circ} 24,2013$.

Cock, Víctor. Derecho cambiario colombiano. Comentarios a la Ley 46 de 1923 sobre instrumentos negociables, Bogotá, I948.

CoRTÉs, ÉDGAR. La culpa contractual en el sistema jurídico latinoamericano, Bogotá, Universidad Externado de Colombia, 2009.

De Cupis, Adriano. El daño. Teoría general de la responsabilidad civil, trad. Ángel Martínez Sarrión, Barcelona, Bosch, I970. 
Gerscovich, Carlos G. Consumidores bancarios. Derechos económicos de los bancos y sus clientes, Buenos Aires, Abeledo-Perrot, $20 \mathrm{I}$.

Hinestrosa, Fernando. Derecho civil. Obligaciones, Bogotá, Universidad Externado de Colombia, I969.

Hinestrosa, Fernando. Tratado de las obligaciones, Bogotá, Universidad Externado de Colombia, 2007.

Hudson, Alastair. The Law of Finance, London, Sweet \& Maxwell, 20 I 3.

Josserand, Luis. Cours de droit civil positif français, t. 2, Paris, Librairie du Recueil Sirey, I932.

Josserand, Luis. Derecho civil, t. II, vol. i, Teoría general de las obligaciones, Bosch, I950.

Larroumet, Christian. Droit civil. Les obligations, t. 3, Paris, Economica, I 986.

Martínez Neira, Néstor Humberto. Sistemas financieros, Biblioteca Felabán, Bogotá, I994.

Mazeud, Henry y Léon, y Tunc, André. Traité théorique et pratique de la responsabilité civile délictuelle et contractuelle, $5 \cdot{ }^{\mathrm{a}}$ ed., Paris, Montchrestien.

Neme Villarreal, Martha Lucía. “Buena fe subjetiva y buena fe objetiva”, $R e$ vista de Derecho Privado, Universidad Externado de Colombia, n. ${ }^{\circ}$ I $7,2009$.

Ravassa Moreno, Gerardo José. Títulos valores nacionales e internacionales, Bogotá, 2006.

Ripert y Boulanger. Traité de droit civil: d'après le traité de Planiol, vol. 2, Paris, LGDJ, I956.

Rocha, Antonio. "Prólogo" a Gabriel Escobar Sanín, Negocios civiles y comerciales, t. I, Bogotá, Universidad Externado de Colombia, I986.

Rodner, James-Otis. El crédito documentario, Caracas, i989.

Rodríguez Azuero, Sergio. Contratos bancarios. Su significación en América Latina, Legis, 2009. 
Rodríguez Olmos, Javier Mauricio. “La interpretación de los contratos con el consumidor: elementos para la contextualización de la problemática", $R e-$ vista de Derecho Privado, Universidad Externado de Colombia, n. ${ }^{2}$ 4, 20 I 3.

Roppo, Vincenzo. Instituzioni di diritto privato, Bologna, Monduzzi, I994.

Santos Ballesteros, Jorge. Instituciones de responsabilidad civil, t. I, Bogotá, Universidad Javeriana, 2006.

Sarmiento García, Manuel Guillermo. Estudios de responsabilidad civil, Bogotá, Universidad Externado de Colombia, 2002.

Sarmiento García, Manuel Guillermo. La responsabilidad en el transporte aéreo de personas, tesis de grado, Universidad Externado de Colombia, I978.

Tafur Morales, Francisco. La nueva jurisprudencia de la Corte. Óptima, Bogotá.

Viney, Geneviève. Tratado de derecho civil. Introducción a la tesponsabilidad, trad. Fernando Montoya, Bogotá, Universidad Externado de Colombia, 2007, 380.

Zafra Roldán, Gustavo y Álvarez Londoño, Luis Fernando. "La responsabilidad de los bancos por el pago de cheques falsos”, Vniversitas, Pontificia Universidad Javeriana, 98, 2000.

\section{Jurisprudencia}

Cas. francesa. Sentencia de i 6 de junio de i 897 .

Corte Constitucional. Sentencia C-roo8 de 20 Io, M.P.: Luis Ernesto Vargas Silva.

Corte Constitucional. Sentencia C-909 de 20 г 2, M.P.: Nilson Pinilla Pinilla.

Corte Suprema de Justicia, Sala de Casación Civil, sentencia del. 26 de noviembre de i965, M.P.: Aníbal Cardoso Gaitán.

Corte Suprema de Justicia, Sala de Casación Civil. Sentencia del 9 de diciembre de I936, M.P.: Antonio Rocha, xLIV, 405-4I 5.

Corte Suprema de Justicia, Sala de Casación Civil. Sentencia del I 4 de marzo de I938, M.P.: Ricardo Hinestrosa Daza, xLVI, 2 I I-223.

Corte Suprema de Justicia, Sala de Casación Civil. Sentencia del i 8 de mayo de I 938, M.P.: Fulgencio Lequerica Vélez, XLvi, 5 I 5-522. 
Corte Suprema de Justicia, Sala de Casación Civil. Sentencia del i 5 de julio de I938, M.P.: Juan Francisco Mújica, XLvi, 724-725.

Corte Suprema de Justicia, Sala de Casación Civil. Sentencia del i I de marzo de I 943, M.P.: Isaías Cepeda, Lv, 48-52.

Corte Suprema de Justicia, Sala de Casación Civil. Sentencia del 7 de abril de ı964, M.P.: Julián Uribe Cadavid.

Corte Suprema de Justicia, Sala de Casación Civil. Sentencia del 6 de marzo de ı 972, M.P.: Humberto Murcia Ballén, CXLII, 98-ıo6.

Corte Suprema de Justicia, Sala de Casación Civil. Sentencia del 29 de noviembre de i976, M.P.: Humberto Murcia Ballén, CLII, 52 2-ıo6.

Corte Suprema de Justicia, Sala de Casación Civil. Sentencia del 24 de octubre de r 994 , exp. $435^{2}$.

Corte Suprema de Justicia, Sala de Casación Civil. Sentencia del i 4 de junio de 2000 , exp. 5025 .

Corte Suprema de Justicia, Sala de Casación Civil. Sentencia del 3 I de julio de $200 \mathrm{I}, \exp .583 \mathrm{I}$.

Corte Suprema de Justicia, Sala de Casación Civil. Sentencia del I 5 de julio de 2005 .

Corte Suprema de Justicia, Sala de Casación Civil. Sentencia del 29 de septiembre de 2006, exp. I IOOI-3103-OI9-I992-20I39-OI.

Corte Suprema de Justicia, Sala de Casación Civil. Sentencia del I 7 de octubre de 2006, M.P Cesar Julio Valencia Copete.

Corte Suprema de Justicia, Sala de Casación Civil. Sentencia del r 6 de junio de 2008, exp. I IOOI-3 IO3-007-I995-OI 394-OI.

Corte Suprema de Justicia, Sala de Casación Civil. Sentencia del 24 de agosto de 2009, exp. IIOOI-3103-038-200I-OIO54-OI.

Corte Suprema de Justicia, Sala de Casación Laboral. Sentencia del ig de febrero de 2002 , EXP. I 7429. 